\title{
Human Centric Food : A Qualitative Analysis of Jeonju's Local Food System
}

Master's Thesis written by Susan Ryu

\author{
School of Architecture \\ Department of Urban and Environmental Planning \\ May, 2017
}




\section{Table of Contents}

\section{Abstract}

\section{Ch.1 Introduction}

1.1 Research Problem

1.2 Thesis Objectives

1.3 Methodology

1.4 Jeonju in South Korea

Ch. 2 Literature Review

2.1 Food System in Urban Planning

2.2 Resilient City

2.3 Formality and Informality inside the City

2.4 Community-Oriented City

Ch. 3 Informal + Formal $=$ Food in Jeonju

3.1 Hidden Rules Inside Informality

3.2 Formality will Enhance Informality

Ch. 4 Socio-Cultural Benefits of Food System in Jeonju

4.1 Connected Lives

4.2 Flexibility of Economic Exchange

4.3 Share-ability is Generosity

4.4 Reflection on Cultural and Social dynamics

Ch. 5 Ecological Impact of Local Food System in Jeonju

5.1 What is Local Food in Korea?

5.2 Food Miles and Waste

5.3 "Natural Farming is Healthy"

Ch.6 Conclusion

6.1 Limitations

6.2 Conclusion

6.3 Future Recommendations

\section{Appendix}

Works Cited 


\begin{abstract}
This thesis explores the relationship of the local food system and socio-ecological resiliency in a city called Jeonju, South Korea. In this paper, I analyze the existence of a local food system that co-produces a city which increases a city's socio-ecological resilience. The study was conducted through methods of participant interviews, observation, and archival research based on qualitative analysis. This paper contributes to the debates of the micro scale food system in average sized city in Korea and its linkage to the resiliency in local food system.
\end{abstract}

\title{
Ch. 1 Introduction
}

\subsection{Research problem}

In the 21st century where most dramatic changes are occurring in our environment, some of the important terms mentioned in human society are 'emergency' and 'crisis'. Even with the changing dynamics of our environment and cities, current city planners and urban designers fail to recognize this in the planning of a city. In order to make cities more resilient to changing dynamics, urban planners should consider flexibility in urban space planning that cooperates with informal practices. Food is one of the most important factor that deals with dynamics since it is one of our basic necessity. As more changes are occurring in our environment that is impacting our food system, the more we are prone to incapable of bouncing back from lack of resources. Incorporating food system in urban planning has been a recently developed concept that is starting to gain acknowledgments from city designers. The question of how food production ties back to a resilient community and the values associated with food production can be analyzed through determining whether it enhances the quality of living for the city residents. Through analyzing a case study of a local food system inside the city of Jeonju in South Korea, I am going to discuss about utilization of city space where food system is recognized in local scale and whether it really benefits the community with more 
opportunities for community engagement thus establishing a self- sustaining and resilient city.

Hypothesis: Informal practices in local food systems reflects a cultural and social dynamics which increase city of Jeonju's resilient food system

\subsection{Thesis objectives}

The objectives of this project are to:

1. Identify and document utilization of city space where food is recognized in local scale of city of Jeonju

2. Define relationship between food system and resilient community through analyzing the case study of Jeonju's local food system

3. Determine whether incorporation of food system benefits the community with more opportunities for community engagement

4. Analyze a case study of cooperation of informal and formal sector of Jeonju's street market

\subsection{Methodology}

For my research, I stayed with my family and conducted site visits of Jeonju for two months, from June 1st to August $1^{\text {st }}, 2016$. This project was an explanatory research project that analyzed a case study of local food system in Jeonju, South Korea. I focused on qualitative data analysis along with the representation of local food system sites inside Jeonju. Four main tools for data collection were used for my research: archival research, observation, interviews with the food system participants and mapping the visualization of the food distribution/production in the city that shows the means of participants' traveling mode and sites’ location.

In order to find a suitable research site, I started with observation of many food system related activities happening in Jeonju. Information that I got for site selection was from a nonreactive observation, also called an unobtrusive observation, conducted of 
people who are unaware of being studied ${ }^{1}$. The observation took place in Samchun market in Samchun dong and Nambu market in Jeon dong for three days in a row. Observation times varied from Nambu market and Samchun market since opening time of the markets differed. Because Nambu market is a more formalized market that opened early in the morning, I have decided to observe the market from 7:00 AM to10:00 AM. The observation time of Samchun market had to take from 3:00PM to 6:00PM, due to the restriction of business time from the local government that allowed the sellers to conduct business. Engaging in a nonreactive observation had made me to gather information and observe what the surrounding environment of the market is and how the market functions, such as how the sellers come to the same spot to sell every day. Location of the major food markets were narrowed down to two, Nambu market and Samchun market and how the informal practices exist in Jeonju's local food system was also observed as well. Through observation is how I defined two major food system related activities that took place inside the city, farming and selling/buying of the food.

My main method for data gathering was interviews with the participants. The reliance on the interview to produce narrative is not only emphasized in social research but also in other field of research as well, for the reason of faith that interviewing results is true and accurate portrayal of the respondents' selves and lives. ${ }^{2}$ During the site visitation, I conducted 12 individual interviews from each category: six farmers engaging in either formal or informal farming, one informal seller from Samchun market, two formal sellers from Nambu market, two buyers from Samchun market, and one buyer

\footnotetext{
${ }^{1}$ Denzin, Norman K., and Yvonna S. Lincoln. The Sage handbook of qualitative research. Los Angeles: Sage, $2018: 732$

2 Denzin, Norman K., and Yvonna S. Lincoln. The Sage handbook of qualitative research. Los Angeles: Sage, $2018: 698$.
} 
from Nambu market. Interviews have been conducted verbally with oral consent following the protocol form of International Review Board of Social and Behavioral Sciences. Engaging in interview process helped me to create a narrative of the local food system and enabled me to get the basic set of data which helped me to approach my research in a deeper understanding of the entire local food system in Jeonju.

Archival research was another method that helped me to understand how the local food system sites have been formed. Archival data such as zoning ordinance map, land use confirmation plan of all the ecological protection area and current status document of illegal street food market vendors from gus were consulted through gu government agency, local dong government agency and lastly from an overarching top tier regulatory institution, the Jeonju city government. These archival records have helped me to gather the data that was informally given to me, which helped me to have a better understanding of the concept of the cooperation of informal and formal institutions in local food system, a complementary method that helped me enhance the defining and collecting the data. ${ }^{3}$

Lastly, I have created two diagrams and a map that represent the approximate location of where the local food system participants reside and how far the participants travelled to get to the food system sites. This representation tool was created to fully aid the analysis and visualization of the transportation mode and the average distance of all local food system participants.

\subsection{Jeonju in South Korea}

\footnotetext{
${ }^{3}$ Elder, G., Pavalko, E. K., \& Clipp, E. C.(1993).Working with archival lives: Studying lives (Sage University Papers on Quantitative Applications in the Social Sciences, 07-088).Newbury Park, CA: Sage.
} 
Meaning "perfect region” in Korean and a capital city of North Jeolla province, Jeonju is a city in South Korea well known for a tourist center for traditional Korean food, cultural and traditional buildings. Located in the heart of Jeonju, Hanok Village is a popular tourism site filled with traditional-style village, housing over 800 traditional "hanok" buildings that retained its historical charms and traditions. ${ }^{4}$ Jeonjus' total area is 206.22 knI with population of 653,887 residents $^{5}$, divided into 2 administrative districts; northern district called Deokjin-gu, made up of 15 dongs (neighborhoods) and southern district called Wansan-gu consisted of 18 dongs. The names of each neighborhood represent geographical surroundings of the neighborhood and so does the name of the market. Jeonju is a city mix of urban and rural with many small scale farming inside the city and had been an important regional center in the province for centuries. Growing up in my hometown Jeonju, I witnessed some of the major developmental changes that happened throughout. As Jeonju started getting densely industrialized, many of the agricultural sector started disappearing. 1990's was the times when Korea actively jumped itself into the global economy along with international food trade policies that resulted in a heavy reliance on global food production system. Having many of my family members who participate in agricultural sector that experienced these changes, I got interested in food system in Korea vs. other countries, which worked vastly different in a global context.

\footnotetext{
4 "Jeonju Hanok Village [Slow City] (전주한옥마을 [슬로시티]) | Official Korea Tourism Organization". English.visitkorea.or.kr. N.p., 2017. Web. 27 Apr. 2017.

5Jeonju City Council. "Current Status." N.p., n.d. Web. 27 Apr. 2017.

<http://jeonju.go.kr/index.9is?contentUid=9be517a74f8dee91014f920f4d7e10bb>.
} 
Agriculture and food has been closely tied to the development of values of Korean culture and community, and to this day, South Korea's major banking institution Nonghyup, is an agricultural cooperation federation that shows agriculture is a center importance in Korea. All of local food system participants, including myself, grew up learning many of social traditions and cultural heritage associated with food system inside the city which is not always necessarily formalized in records or researched in a field of academics. An example can be found in food market system as well, such as Nambu market, meaning 'southern market' that was built where the market used to exist historically in the southern downtown Jeonju, next to the tourist area Hanok Village. A formal marketplace was built in the middle section of the Nambu market, which consists mostly of professional middleman merchants' shops along with a series of cubbies in the edge occupied by informal sellers (figure 1 and 2). With all informal and formal merchants participating, the market functions as a one giant food market, with informal merchant cubbies existing in an open air and the formal middle marketplace representing more like an in-door shopping center. Nambu market is also called a 'traditional market', since the market's location and values are derived from the tradition and cultural values associated within the community (figure 4). This kind of knowledge associated with socio-cultural context is spread from word to word in between participants and is uniquely learned and kept by the local natives of the city.

Around the edge of Wansan-gu, there exists a neighborhood called Samchun dong, which translates into a three river neighborhood. Samchudong's name reflects the geography of the neighborhood where the three major rivers of Jeonju come together, which are coming from Gui valley, Joong-In Valley and Jang-Seung-Bak-Ee Valley 
adjacent to Jeonju. ${ }^{6}$ Samchun dong's local food market, Samchun market is one of the biggest open-air informal food market existing in Jeonju, 700 meters long and 750 squares meters big (appendix 2, figure 3).

Surrounded by a basin, Jeonju has many mountains surrounding its edge of the city. One of the major Jeonju's mountains in Deokjin-gu, Mt.Gunji is a mountain where many of the agricultural activities are taking place. Korean National Land Planning \& Utilization Act appoints city officials to authorize land use districts under Article 37 and let city officials designate Mt.Gunji as a 'natural green district' in the zoning ordinance map of Jeonju (appendix 5). Natural Green district is forbidden from building commercial buildings but allowed for agricultural activities according to Article 51 of Land Planning \& Utilization Act which meets the criteria of Architectural Criteria for the Construction for the Land Use District (appendix 4). There are other purposes of protection for Mt.Gunji, which follows the guideline of Land Use Planning Manual (appendix 3) and Land Registration map (appendix 1). These purposes qualify Mt.Gunji to be protected from development of the commercial or industrial buildings according to Article 76, which protects the water stream that runs through the mountain for protection of drinking water quality and Article 83, which forbids the development of the natural environment around schools.

Compared to major cities such as Seoul, a smaller average-sized city such as Jeonju has often been understudied in urban studies research. This often undermines the importance of the smaller cities in Korea which ties back the importance of micro -scale

\footnotetext{
${ }^{6}$ Ibid.
} 
in local food system that makes a suitable research site for potential opportunities of urban local food system, making a valuable case study for small cities.

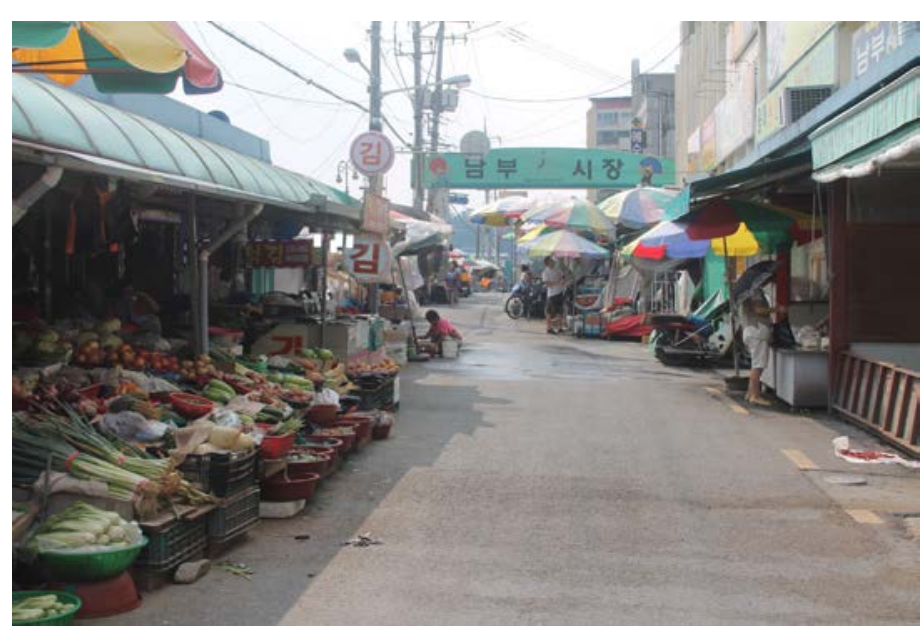

Figure 2 Nambu market entrance

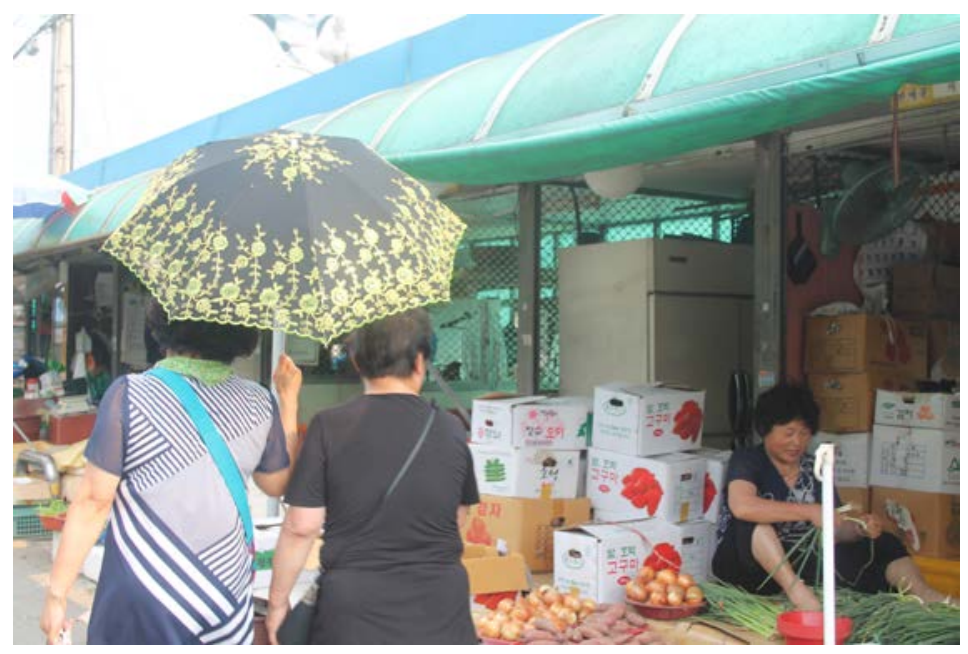

Figure 1 Informal cubbies in Nambu market

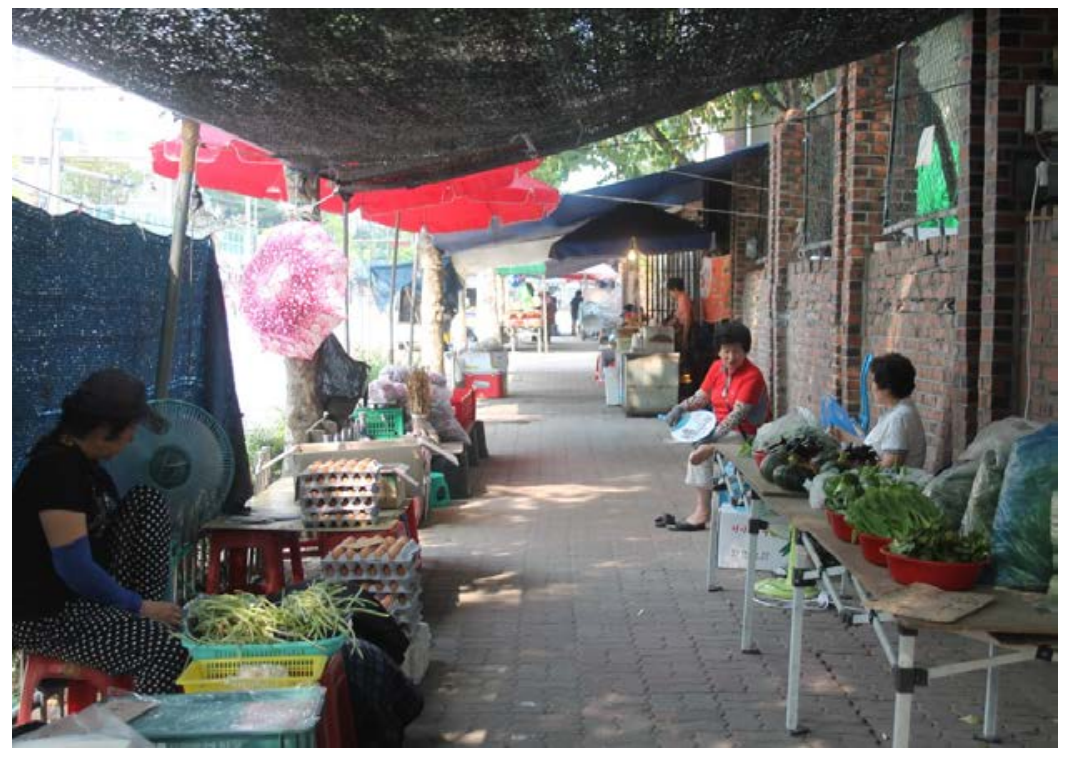

Figure 3 Samchun Market

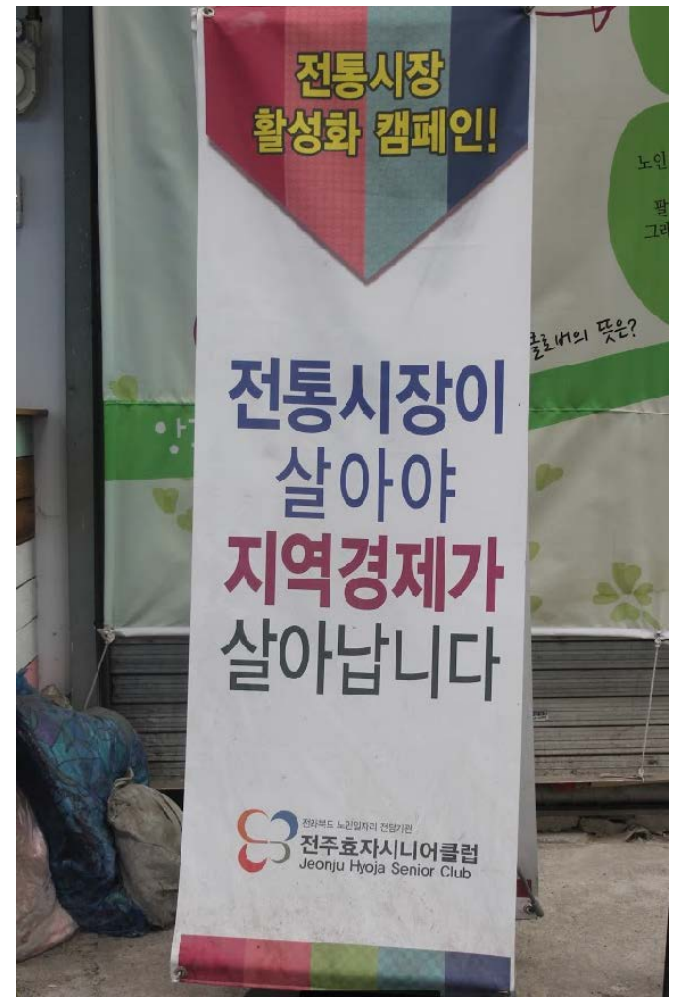

Figure 4 a banner that says "Traditional market saves your local economy" in Nambu market 


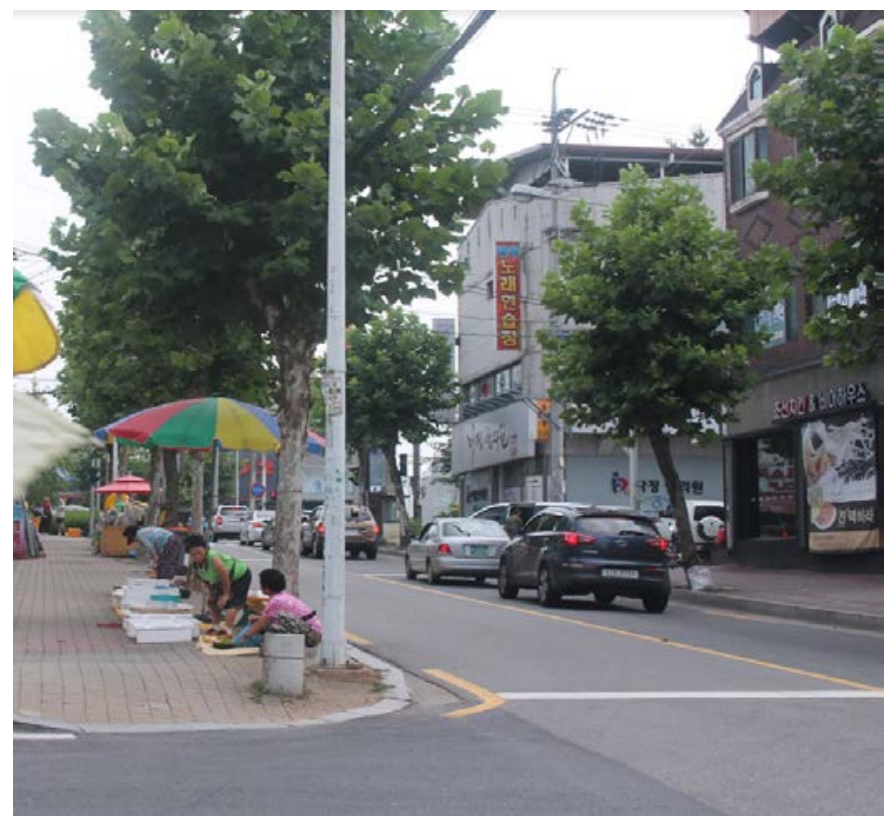

Figure 7 sidewalk view of Samchun market

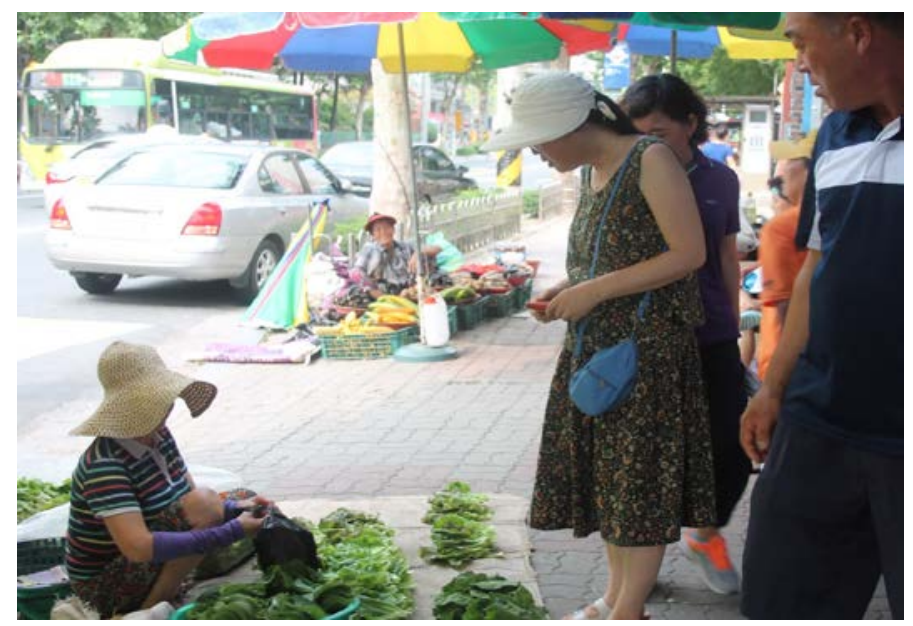

Figure 6 seller and buyer's interaction in Samchun market

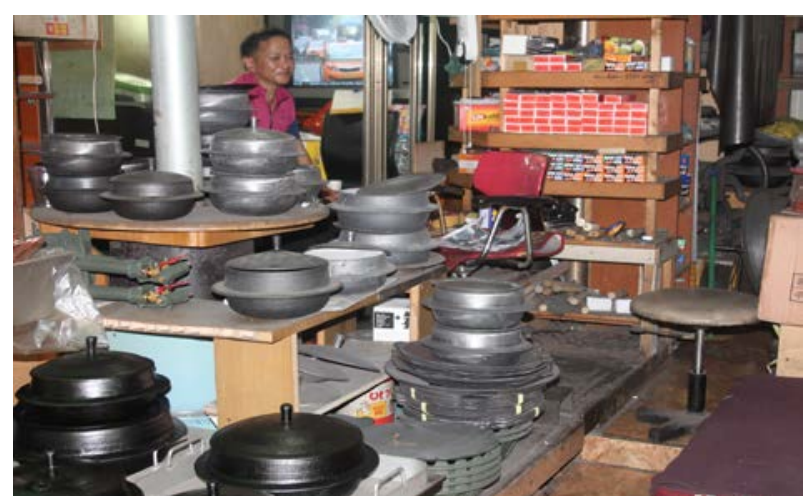

Figure 5 Inside Nambu market

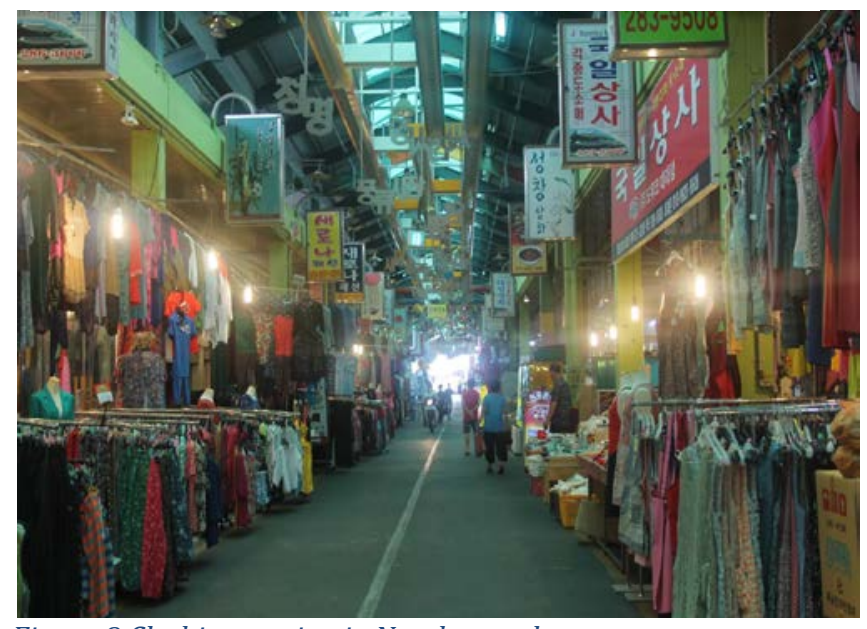

Figure 8 Clothing section in Nambu market

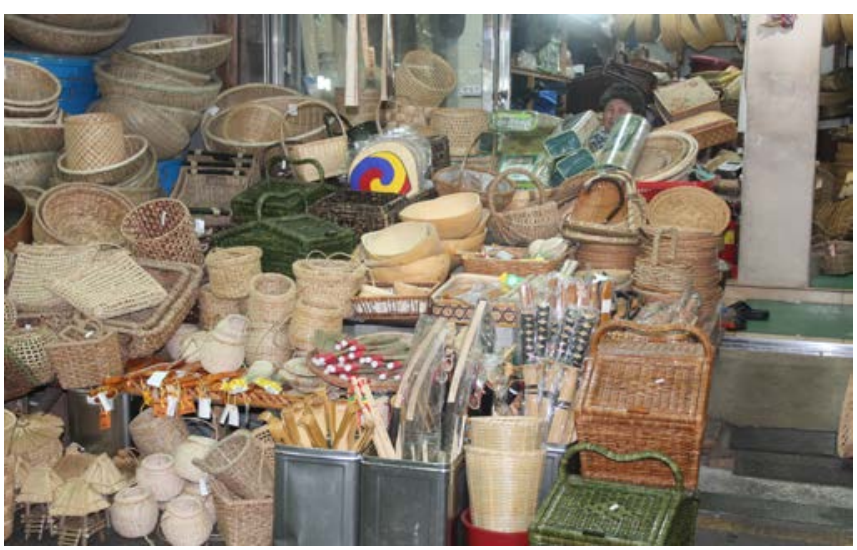

Figure 9 Basket market vendor inside Nambu market 


\section{Ch.2 Literature Review}

\subsection{Food System in Urban Planning}

In the last four decades, the earth has changed in various ways. ${ }^{7}$ Tropical weather and the lack of heat have led to reductions in 40 million tons of crops such as wheat, corn and barley every year. ${ }^{8}$ One of these major changes are environmental changes that also have impacts on our basic needs in our society, such as food and water.

Food security is defined as the state where all community members have access to “culturally acceptable, nutritionally adequate food through local, non-emergency sources at all times.” ${ }^{9}$ In the US, at least $12 \%$ of households are affected by limited food supply in a given year. ${ }^{10}$ The number of people affected increased from 33 million in $2001^{11}$ to 45 million in 2010 and in the future, by 2050, 67\% of the world's population will live in cities with food shortage. ${ }^{12}$ Accessibility, affordability, and availability of food are the three core aspects of food security ${ }^{13}$ that cannot be completely ensured in urban spaces. This kind of food insecurity is addressed through rapid urbanization. Cities are becoming more aware about how they feed themselves due to the food shortages, since food system is most politically volatile areas in every country. ${ }^{14}$

In order to cope with these changes, cities must be more dynamic and more resilient to change. Resilient cities are cities that know how to 'bounce back', with a

\footnotetext{
${ }^{7}$ McKibben, Bill. 2010. Eaarth. 1st ed. New York: Times Books. 2.

${ }^{8}$ Ibid., 6.

${ }^{9}$ Brown and Carter, 2003 in Opitz, Ina, Regine Berges, Annette Piorr, and Thomas Krikser. 2015.

"Contributing To Food Security In Urban Areas: Differences Between Urban Agriculture And Peri-Urban Agriculture In The Global North". Agriculture And Human Values 33 (2): 342.

${ }^{10}$ Macias, 2008 in Ibid.

${ }^{11}$ Brown and Carter, 2003 in Ibid.

12 United Nations, 2012 in Ibid.

${ }^{13}$ Lang and Barling, 2012 in Ibid.

${ }^{14}$ Morgan and Sonnino, 2010 in Morgan, Kevin. 2009. "Feeding The City: The Challenge Of Urban Food Planning". International Planning Studies 14 (4): 342.
} 
socio-ecological resilience theory understanding urban systems change in ways that are not always linear, in a relevant manner for dealing with future disaster uncertainties. ${ }^{15}$ Resilience is adaptive and transformative, creating a change for rethinking assumptions and building new systems. ${ }^{16}$ As a result of communities dealing with demands for limited resources, planners should be able to make food system planning of the utmost importance for action. It is the government that should begin to work to improve local food systems as a strategy to improve local food system and sustainability. ${ }^{17}$

Local food system is "food produced, processed and distributed within a particular geographic boundary that consumers associate with their own community.”18 In regards to any food system related activities, the range of definition include "on-farm production to marketing, selling and processing to distribution.”19 Local food system activities in a city defines and enhances many of the actions that are related to community and localism. It differs from the macro scale of global industrial agriculture in that it connects all elements of the food system such as the growing, processing and distributing to a defined geographic region. Local food system makes an important contribution to its community, including business development, expansion, the development of new

\footnotetext{
${ }^{15}$ Meerow, Sara, Joshua P. Newell, and Melissa Stults. 2016. "Defining Urban Resilience: A Review". Landscape And Urban Planning 147. 39.

${ }^{16}$ Maguire and Cartwright, 2008, in Petcou, Constantin, and Doina Petrescu. 2015. "R-URBAN or how to co-produce a resilient city." Ephemera: Theory \& Politics In Organization 15, no. 1. 255.

${ }^{17}$ Roberts, 2009, Roseland, 2012, Astyk and Newton, 2009 in Buchan, Robert, Denise Cloutier, Avi Friedman, and Aleck Ostry. 2015. "Local Food System Planning: The Problem, Conceptual Issues, And Policy Tools For Local Government Planners". Canadian Journal Of Urban Research Summer 24 (1). 4. ${ }^{18}$ Ibid. 5.

${ }^{19}$ Staaz, 2000 in Urban AgriCulture and Food Systems Dynamics in the German Bonn/Rhein-Sieg Region. International journal on food system dynamics 7, no. 4.343
} 
business relationships and providing fresh food to consumers ${ }^{20}$ and creating a system that reduce food miles.

Food distance, miles or kilometers measure the distance that food travels from farm to plate which determines that the larger the distance has the larger the impact on our environment. Originally, the environmental impact of food miles was thought about in larger fashion, ${ }^{21}$ but the concept of 'enhanced food miles' that includes social, and economic external costs is comprised in the definition of food mile as well. The enhanced food miles also relate to differences in transport mode and efficiency. "There are major differences in external costs between different transport modes, e.g. air transport that has a very high environmental impact while the impact of sea transport is relatively low compared with road transport." 22

Instead of relying itself on the state or business infrastructures, the idea of local food system is to eliminate the exploitative middle men in the food market business. One market most commonly associated with local food systems in the US are the farmers' markets. ${ }^{23}$ Markets generate significant income and has societal benefits for vendors and the surrounding neighborhoods. Instead, farmers connect with the small-scale processors, shops or directly with consumers who buys fresh produce directly from the farm. Direct economic exchange with the food producers often results in an enthusiasm about the food quality and about the exchange manners. The joy of a direct connection between producers and consumers is that they share the same notion about food. Both the

\footnotetext{
${ }^{20}$ Hultine, S. and Cooperband, L.,2008 in Inman, Patricia. 2017. "Locally Produced Food: A Way To Grow". Policy Profiles 15 (2): 4.

21 Van Passel, Steven. 2010. "Food Miles To Assess Sustainability: A Revision". Sustainable Development 21(1): 1-17.

22 Ibid.

23 "Marketumbrella.Org | News". Marketumbrella.org. N.p., 2017.
} 
consumer and the producer want fresh quality of food with a non-exploitative price in food which creates a social life. Direct communication between producers and consumers creates a responsive economic system by the needs of society rather than the needs of big business. Local food markets create consumer demand for a wide range of products that are valued for their taste and nutritional content, rather than their ability to endure longdistance transport or accommodate to a large scale supermarket blueprint. As well as providing a direct employment, local food system also help sustain many other small scale producers and shops in a local community. This is why the local food system is critical to the survival of local communities. ${ }^{24}$

The urban or peri-urban local food system enables the community to become the co- producers or more actively to engage in direct relationship in a community. By directly selling/ buying food and producing food in a city space, it hypothesizes the necessity to engage community residents in the public services where these services have become inefficient and need reforming, and where the higher institutional state is no longer there to coordinate them. ${ }^{25}$ This kind of local food system is an important driver for individual innovation in the development of stronger horizontal and local networks. Local and horizontal food networks “create an entirely new way of doing business that focuses on sharing rather than having. The 'sharing' part of economy operates in the absence of large head offices and associated vertical structures, based on trust between individuals.”26 Bottom-up initiatives development naturally increases resiliency since it requires a "shift from upscaling towards downscaling: rather than looking for a country-

\footnotetext{
24 Norberg-Hodge, Helena. 1999. "Reclaiming Our Food : Reclaiming". The Ecologist 29(3): 210.

${ }^{25}$ Pectou and Petrescu. 249.

${ }^{26}$ Kupers, Roland. Turbulence: A Corporate Perspective On Collaborating For Resilience. 1st ed. Amsterdam University Press, 2014.
} 
wide solution to address all challenges at once, start small and replicate successful approaches quickly. It also needs shifting in perspective: rather than looking forward and looking around."27

The belief that food production is limited to a rural activity fails to recognize the significance of urban agriculture, as food production is an "activity that never disappeared and one which is re-appearing in the more sustainable cities of the global north, where urban designers are re-imagining the city as a farm space.”28 In the past, large parcels of property were zoned for agriculture which was easily identified by zoning labels. Now smaller farms have the options for cultivation on the edge of the cities as well as rural area. ${ }^{29}$ Urban agriculture does not have one geographical definition and, as such, urban farms can be located in the urban core or in the surrounding peri-urban areas. ${ }^{30}$ Therefore urban agriculture (UA) is "any agricultural activities which grows, raises, processes and distributes agricultural products regardless of land size and number of human resources within the cities and towns.”31

The range of urban agriculture activities varies from community gardens to commercial farms and their main stated goal is food production. However, the other goal of growing food can also contribute to social interest in which that builds a community awareness about food system. The classification of which agricultural activities should be

\footnotetext{
${ }^{27}$ Ibid.

${ }^{28}$ Morgan, Kevin. 2009. "Feeding The City: The Challenge Of Urban Food Planning". International Planning Studies 14 (4): 343.

${ }^{29}$ Inman, Patricia. 2017. "Regional Food Systems As Engines : How Do Universities Engage?". Social Alternatives $34.2: 42$.

${ }^{30}$ Mougeot, L.J. 2000. “Urban agriculture: definition, presence, potentials and risks”, in Bakker, N.,Dubbeling, M., Guendel, S., Sabel-Koschella, U. and de Zeeuw, H. (Eds), Growing Cities, Growing Food: Urban Agriculture on the Policy Agenda, DSE, Eurasburg : 1-42.

${ }^{31}$ FAO, 2000 in Rezai, Golnaz, Mad Nasir Shamsudin, and Zainalabidin Mohamed. 2016. "Urban Agriculture: A Way Forward To Food And Nutrition Security In Malaysia". Procedia - Social And Behavioral Sciences 216: 40.
} 
considered as farms is unclear, for "in particular, the presence of about 18,000 community gardens in the USA and Canada suggests many perceived benefits from community gardening, but whether these gardens should be classified as farms is not clear.”32 A general difference between a community garden and a farm can be perceived as the usage of production. Whereas community garden is meant for home use, farm output is intended for the market. But even if community gardens are considered as farms, there are no given data that describes the locations, size and production of community garden. ${ }^{33}$ The line between an urban farm and a community garden is hazy, but many of the case study treat urban farms and community gardens alike. ${ }^{34}$

There are many different groups and actors involved in urban agriculture ${ }^{35}$ and the motivations behind it is all different. UA's framework has a higher degree of independence from traditional food production factors that leads to a large range of programs and activities. This diversity occurs on all levels, from individual interests as well as on a supra-individual which has a direct societal impact. UA deals with many aspects of social and economic life, which gives a societal restriction by providing a cultural ecosystem services. ${ }^{36}$ In a city, UA can be a driving economic factor with regards to food security and contributes to raising the city economy, which can lead to better resilience. ${ }^{37}$

\footnotetext{
${ }^{32}$ American Community Gardening Association. Undated. Frequently Asked Questions.

${ }^{33}$ Rogus, Stephanie, and Carolyn Dimitri. 2014. "Agriculture In Urban And Peri-Urban Areas In The United States: Highlights From The Census Of Agriculture". Renewable Agriculture And Food Systems 30 (01):65.

${ }^{34}$ Cohen, N., Reynolds, K. and Sanghvi, R. 2012. "Five Borough Farm: Seeding the Future of Urban Agriculture in New York City”. Design Trust for Public Space, New York, NY.

${ }^{35}$ Van Veenhuizen, R. Cities Farming for the Future-Urban Agriculture for Green and Productive Cities; RUAF Foundation, IDRC and IIRR Publishing: Silang, Philippines, 2006.

${ }^{36}$ Krikser, Thomas, Annette Piorr, Regine Berges, and Ina Opitz. 2016. "Urban Agriculture Oriented Towards Self-Supply, Social And Commercial Purpose: A Typology". Land 5 (3): 2.

${ }^{37}$ Ibid. 3.
} 
The character of food can be multifunctional which creates and appeals to a wide range of community movement which is why local planning agency may have an importance in communities in providing an extensive knowledge on food system issues. According to Pothukuchi and Kaufman, planning agencies perform functions in market analyses, data collection for city formation, and evaluation on a wide scope of community concerns. This system may effectively be organized for the process of analysis and management of the food system in cities and its connection to other community systems. "Incorporation of food into planning, however, needs political will, creativity, and above all, acknowledgement of the food system as a vital urban system.”38

In the book Hungry City, Carolyn Steel explains food as a tool that change the world in and beyond the city. One of her key conclusions in her book is that planners have failed to see the potential of food planning, in which that the food system in cities "emerges as something with phenomenal power to transform not just landscapes, but political structures, public spaces, social relationships, cities." ${ }^{39}$ This understanding of food system in urban settings can help designers and planners to take into account the social, economic and environmental changes based in place for both the immediate and longer terms. ${ }^{40}$

\subsection{Resilient City}

\footnotetext{
${ }^{38}$ Pothukuchi, K. \& Kaufman, J.L. 1999. "Placing the food system on the urban agenda: The role of municipal institutions in food systems planning”. Agriculture and Human Values 16: 220.

${ }^{39}$ Steel, Carolyn. 2013. Hungry City. 1st ed.: 307.

${ }^{40}$ Mehmood, Abid. 2015. "Of Resilient Places: Planning For Urban Resilience". European Planning Studies 24 (2): 419.
} 
Resilience is an emerging concept that guides and supports more inclusive and effective approaches to the socio-ecological systems. ${ }^{41}$ Resilient systems are flexible, prepared for dynamics and uncertainty, which is essential for the affluent development of society. ${ }^{42}$ The concept of managing for socio-ecological resilience relates to the maintenance of system properties with their ability to cope and accommodate to future change. ${ }^{43}$ General resilience theory describes a "conceptual model for socio-ecological resilience based on three system characteristics: (1) the amount of disturbance a system can absorb and still retain the same structure and function, (2) the degree to which the system is capable of self-organization, and (3) the degree to which the system can build and increase the capacity for learning and adaptation.”44

The term 'resilience' has its origins in the natural sciences ${ }^{45}$ which refers to the ability of systems enduring shocks in exterior circumstances. The similarities between the natural and social configurations of resilience resemble the ability of a system that hold together and function adaptively in change and shocks from outside. ${ }^{46}$ Social resilience is different from other strategies associated with social responses to global environmental challenges. Social resilience is an intricate and complex concept which may involve an

\footnotetext{
${ }^{41}$ Carpenter, S. and L. Gunderson. 2001. “'Coping with Collapse: Ecological and Social Dynamics in Ecosystem Management.” Bioscience 51:451-57.

${ }^{42}$ Berkes, F. and C. Folke. 1998. "Linking Social and Ecological Systems for Resilience and Sustainability.”' Pp. 1-25 in Linking Social and Ecological Systems: Management Practices and Social Mechanisms for Building Resilience, edited by F. Berkes and C. Folke. Cambridge: Cambridge University Press.

${ }^{43}$ Marshall, N. A. et al. "How Resource Dependency Can Influence Social Resilience Within A Primary Resource Industry". Rural Sociology 72.3 (2007): 364.

${ }^{44}$ Carpenter, S. and L. Gunderson. 2001. "Coping with Collapse: Ecological and Social Dynamics in Ecosystem Management.” Bioscience 51:455.

45 Adger, W.N. 2000. 'Social and Ecological Resilience: Are They Related?’' Progress in Human Geography 24:347-64.

${ }^{46}$ Hopkins, R., 2008. The transition handbook : 12.
} 
active, community-based, internally driven and holistic approach measures aimed at mitigation and adaptation that provide greater protection against external shocks. ${ }^{47}$

In urban planning, the concept of resilience analyzes the relationships between communities and the environment. ${ }^{48}$ Resilient cities contain flexible systems that help consider the dependence between communities and the environment. This perception values cultural and social relation as a critical role in local ecology and environment. The relationship between these social and ecological systems observes the effectiveness of governance, adaptive capacity of the communities, and ecological benefits in ecosystems services. ${ }^{49}$ Thus a community resilience argues that communities, including individual members need to look inward and protect against the inevitable onset of global changes. ${ }^{50}$

\subsection{Community Oriented City}

Community members strongly tied to their community often prefer the stability associated with staying in their community, which can increase their dependency on the adjacent resource. ${ }^{51}$ The correlation of community networks and a resiliency factor is not new. Social capital as defined by Lin is “the resources embedded in one’s social networks which can be accessed or mobilize through ties in the networks." 52 As a concept, whole

\footnotetext{
${ }^{47}$ Barr, Stewart, and Patrick Devine-Wright. "Resilient Communities: Sustainabilities In Transition". Local Environment 17.5 (2012): 525.

${ }^{48}$ Wilkinson, C. "Social-Ecological Resilience: Insights And Issues For Planning Theory". Planning Theory 11.2 (2011): 148-169.

${ }^{49}$ De Groot, Rudolf S, Matthew A Wilson, and Roelof M.J Boumans. 2002. "A Typology For The Classification, Description And Valuation Of Ecosystem Functions, Goods And Services". Ecological Economics 41.3: 400.

${ }^{50}$ Barr and Wright. 2012. 527.

51 Stedman, R.C. 1999. "Sense of Place as an Indicator of Community Sustainability.'” The Forestry Chronicle 75:765-70

${ }^{52}$ Cook, Karen S., Nan Lin, and Ronald Stuart Burt. 2001. Social Capital: A Theory Of Social Structure And Action. 1st ed. New York: Cambridge University Press : Ch.2
} 
community is a means by which residents and community leaders and government officials collectively understand and assess the needs of their communities and determine the best ways to construct and strengthen their assets and interests. ${ }^{53}$ It means that community planning builds resilient strategies within an inward solutions. FEMA argues that the whole community for resiliency in cities is "based on three principles: (1) Understand and meet the actual needs of the whole community; this entails identifying the demographics of a community and understanding the needs of all its members (2) Engage and empower all parts of the community; empowerment provides self-confidence and motivation, and stimulates the awareness for individual preparedness and community contribution. (3)Strengthen what works well in communities on a daily basis; identifying and utilizing those existing structures and relationships that are present on a day-to-day basis ensures that real world solutions are found at the local level." ${ }^{54}$ Local ownership in communities include local decision-making, greater gains of economic revenue from local resources and self-empowerment over resource management. ${ }^{55}$

\subsection{Formality and Informality inside the City}

The downscaling of a food in local food system is widely shown in the case of an 'informal sector', which exists in many forms. Informal sector is comprised of small traders and service providers, legal and illegal activities with a wide array of artisan participants. Finding a one definition of the concept of 'informal sector' is therefore

\footnotetext{
53 "A Whole Community Approach To Emergency Management: Principles, Themes, And Pathways For Action". FEMA FDOC 104-008-1 (2011): 3.

${ }^{54}$ Ibid. 15.

55 Shuman, M. 1998. Going Local: Creating Self-Reliant Communities in a Global Age. New York:

The Free Press.
} 
difficult, given the variety of trading activities the term implies. The same applies to the concept of 'informal food' as well. The most visible activities relating to the informal food sector are food production, transporting or sale of fresh or cooked products in the stationary or street. The informal food sector is not specialized and diversified products are sold with very low capital investment. The informal food trade is interlinked with both production and consumption, with absence of accounts and all or some taxation from the state. ${ }^{56}$

This so-called informal food sector is another type of sector in the economy, which is often times underestimated in their scope and ability to raise revenues. While conventional approaches to the formal economy consider the market as the main matrix for economic actions ${ }^{57}$, socio-economic practices within the informal economy interact with public policies and mainstream development strategies that have various impacts on communities' socio-economic environments. The informal economy resembles a chaotic world that results from formlessness. ${ }^{58}$ However, this apparent deficit applies only to the forms recognized by a formalized institution. Typically, with regard to the incomegenerating activities that constitute this sector is "the lack of a legal form, for example, registration in a trade record and with the tax authorities and social insurance schemes, a form which results from the rationalization process that has historically accompanied the constitution of the nation." ${ }^{59}$ However, formalization does not abolish the earlier norms,

\footnotetext{
56 "The Informal Food Sector Municipal Food Support Policies For Operators". Food and Agriculture Organization of the United Nations 4 (2003): 1-23. Print.

${ }^{57}$ Hillenkamp, Isabelle, Frédéric Lapeyre, and Andreia Lemaître. Securing Livelihoods. 1st ed. Oxford University Press, 2004.

${ }^{58}$ Guha-Khasnobis, B., R. Kanbur and E. Ostrom (eds.) (2006). Linking the Formal and Informal Economy. Concepts and Policies. Oxford and New York: Oxford University Press, WIDER Studies in Development Economics.

${ }^{59}$ Hart, K. (1973). 'Informal Income Opportunities and Urban Employment in Ghana'. Journal of Modern African Studies, 11: 61-89.
} 
rules, and social forms existing in communities, nor does it prevent the emergence of other, equally modern forms of social regulation, especially those adapted to the context of new urban neighborhoods. These norms, rules, and social forms, which coexist, and in many cases compete, with those recognized by state bureaucracy, shaping the practices of what is considered as the 'informal' economy. They provide specific rules and a significant degree of stability and predictability. In order to secure these actors’ livelihood, institutionalist approaches are needed to take into account the complex interactions between the economy, institutions, and social norms. ${ }^{60}$

Therefore the interaction between two parties on what was once considered contradicting has proven to be effectively co-exist in the economy that ensured the benefits of the community's norms and traditions. The formal and the informal should not be understood as opposite and separate domains. The informal and formal conception is both fundamental and non-dichotomous, an overlapping concept rather than two concepts in opposition ${ }^{61}$ which means that 'The informal' and 'the non-legal' coexist and intermingle with 'the formal' and 'the legal' inside the city space." 62

Informality is not a condition that needs a reformation "but rather a contagious phenomenon that actually remakes and humanizes cities." ${ }^{\prime 3}$ It is often in the 'informal city' where the citizens have their right to co-produce the city. Lefebvre argues that In a context of urban transformation, co-production is rooted in the idea of the social

\footnotetext{
${ }^{60}$ Hillenkamp, Isabelle, Frédéric Lapeyre, and Andreia Lemaître. Securing Livelihoods. 1st ed. Oxford University Press, 2004.

${ }^{61}$ Dovey K. 2012. Informal urbanism and complex adaptive assemblage. International Development Planning Review 34 (4), 349-67.

${ }^{62}$ Nuijten M, Koster M, de Vries P (2012) Regimes of spatial ordering in Brazil: neoliberalism, leftist populism and modernist aesthetics in slum upgrading in Recife. Singapore Journal of Tropical Geography 33 (2), 157-70.

${ }^{63}$ Mehrotra R, Hernández F, Kellett P, Allen L. 2010. Rethinking the Informal City: Critical Perspectives from Latin America, xi-xiv. Berghahn Books, New York and Oxford.
} 
production of space, ${ }^{64}$ saying that city space "is not only about the manner in which public needs are to be met, but also about citizens' rights that does not only mean the right to occupy space in it, but also mean to decide how it is developed, managed and used.”65 Therefore planners should design a resilient urban space which knows how to adapt itself to growing food demands, providing a social space where the public needs and demands of co-production is met that raises the sense of local community.

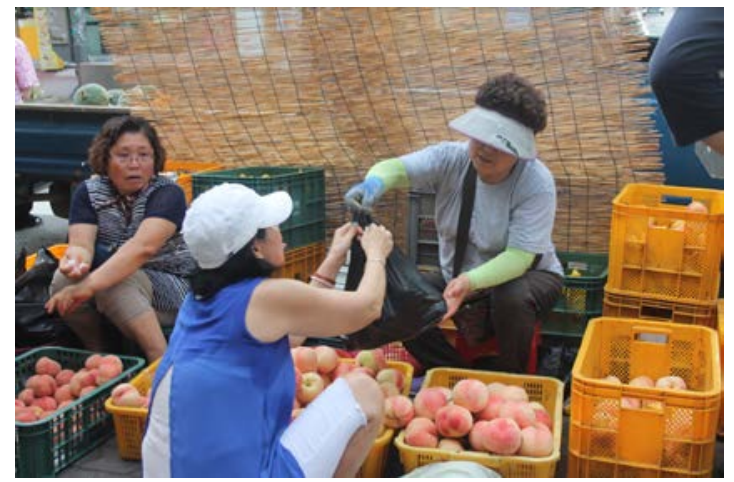

Figure 10 Samchun market

\section{Ch. 3 Informal + Formal $=$ Food in Jeonju}

Food system in Jeon shows cooperation between informal and formal institutions.

What is interesting about this kind of food system is that it challenges the regulatory compliance of the food system. This phenomena is found throughout both food market system as well as farming sector. The cooperation of informal and formal institution is not something that is easily found in Western context, for often times the 'informal' sector is not as supported from informal institutions. I researched about both informal sector and formal sector of local food system in Jeonju, where there was a pattern found in these two sectors cooperating with each other.

3.1 Hidden Rules inside Informality

\footnotetext{
${ }^{64}$ Lefebvre, H. (1991) The production of space. New York: Blackwell.

65 Pectou and Petrescu, 250.
} 
The flow of sellers and buyers' interactions in two selected food market sites, Samchun market, an informal street market located in Samchun-dong and Nambu market, a more formalized market near downtown Jeon dong, were observed for my research. Through observation of Samchun market I was able to learn how the informal market functioned. Around 3:00 PM, informal sellers started to come out with their products to sell for the day. Their products that they brought out differed daily, but sellers who showed up always went to the same spot. Buyers, mostly women, in their 30's to 50's started to come out and shopping around 3:30 PM as well. Samchun market was a very lively market, averaging about 100 pedestrians passing by in 5 minutes either shopping or walking in the sidewalk. Location of how the market developed is unclear but can be assumed that it follows the nature of development around residential apartments in Samchun dong. The reason on why the location development of Nambu market is also not defined, although there was a mentioning from one buyer in Nambu market of its historical location. Shopper Kim, age 56 mentioned that "I think Nambu market was formed naturally due to their location. It is conveniently located near downtown and there were always sellers along the river selling food. These are all the markets that used to exist even when I was young and I remember walking to the market with my parents.” Although not as mentioned in a formal document, one can assume that the location of these markets have arisen due to the centrality of their location as well as convenience of being right next to where residents reside. Compared to Samchun market, the size of Nambu market was much bigger and a lot less lively. This might be due to the size and the sprawl of the market, with all of the market participants differing in gender and ages, although most participants 
seemed to be in their older age.

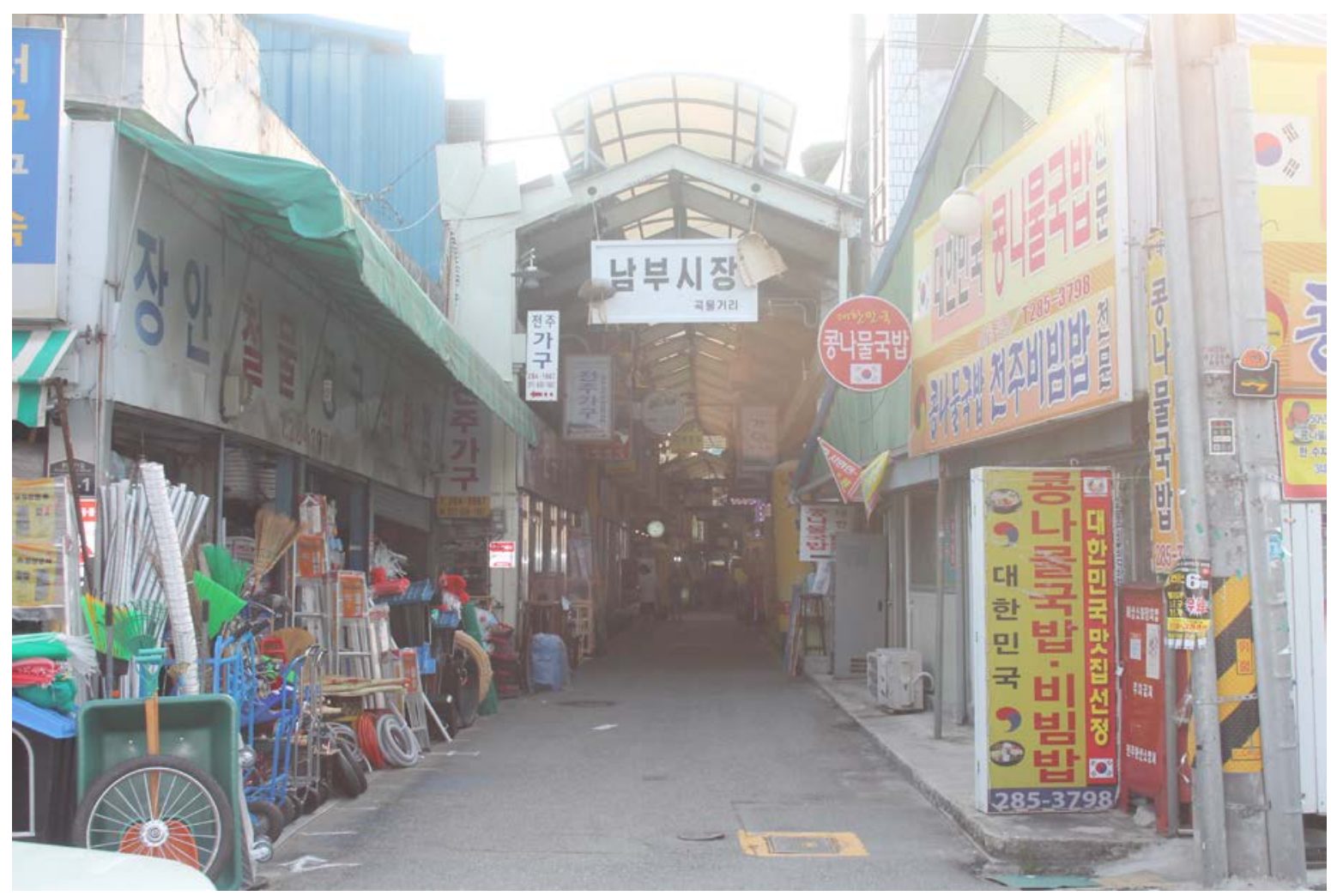

Figure 11 Entrance to "grain street" in Nambu market

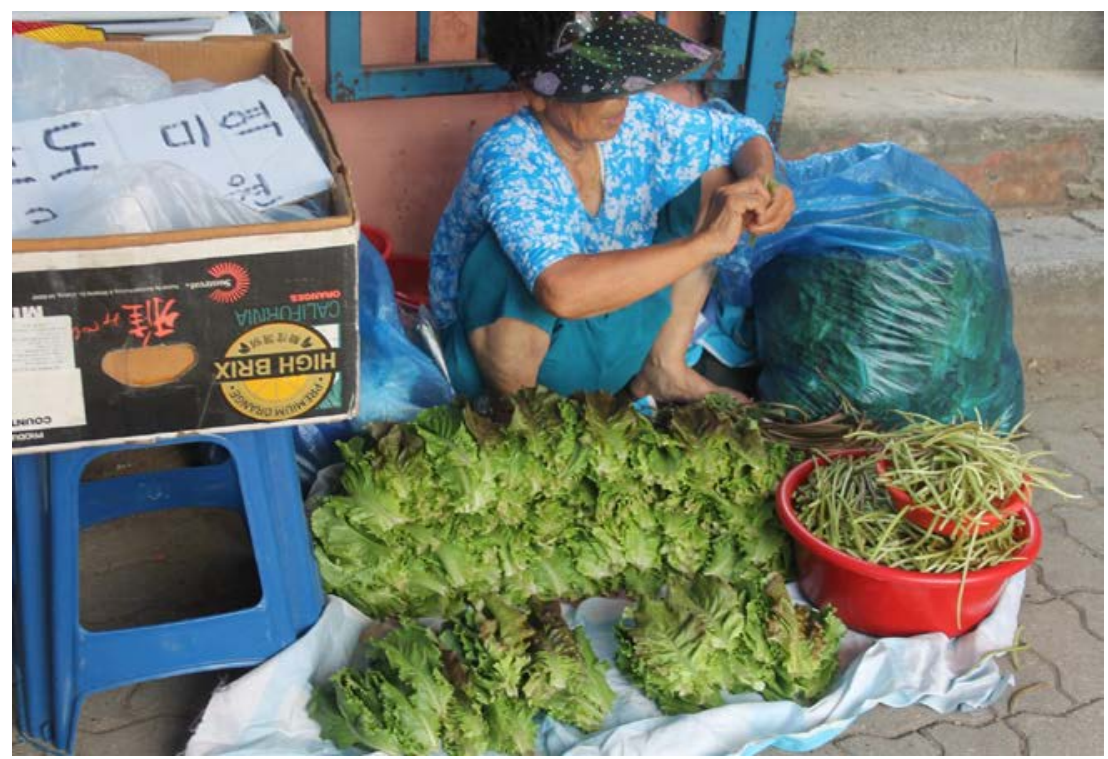

Figure 12 lettuce seller in Samchun market

Observing how the sellers kept going to the same spot even if there was no signage showed that the spot belonged to the merchants led me to question whether the sellers 
already know where their each 'spot' is. According to informal sellers in Samchun market and both Nambu market, there exists a term called, 'sang doduk' which translates as business ethics between the merchants. These merchants function within their informal system. If they want to be part of the market, they have to be the members of the market that have to show manners to each other. Both informal sellers from Samchun market and from Nambu market were part of the informal merchants' union who chose to be part of the community members. For example, a seller from Nambu market, mentions about this rules as follows:

There are rules in all types of markets. If you have been selling in one spot, it is likely that other merchants recognize your spot and that is where your store exists. It is important for these sellers to recognize rules, since it is considered as an order of the market system. Inside a market, lots of things happen and there are lots of talk between merchants as well. It is a place of communication, so one has to watch out if you want to belong to the market. There is also a union for these informal street sellers. They collect fees to go on a vacation together- Seller Sung, 85 years old.

An informal seller from Nambu market, seller Park, age 67, also mentions about the union that she is a member of and the rule that she tacitly follows,

I joined the merchants union and paid a \$2 monthly member fee. You know you have to be a member if you want to get these cubicles. We started paying $\$ 5$ a year to go on a travel. The city is not responsible for any of the business that is happening inside this market.

Informal seller

from Samchun

mentions about the

union that exist in

well, saying “There

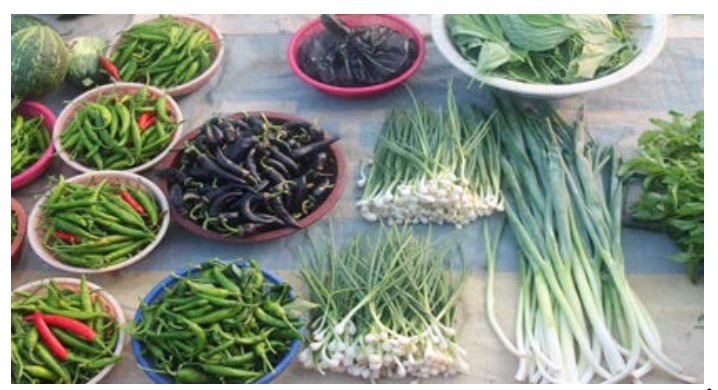

Figure 13 Vegetables sold on Samchun market
Kim, age 65 years old

market (figure 14) also

informal merchants'

Samchun market as

is a union leader whos'

selling peaches in at the end of the market, so if you want to go ask him questions about our union, go ahead and do that. Our union focuses more on socializing and we have a 
yearly fee to pay to go on a travel together.” The rule of acknowledging merchants' spots and respecting the other sellers amongst informal sellers ties back the concept of business ethics in between members, acknowledging their responsibility as community members that values the ethics and morality of the informal business world.

Hidden rules also exist in local food production system. For example, farmers that farm in small parcels of land next to Chonbuk National University follow the rule of making a proper payment for their use of land and acknowledge the other informal
famers that
them.
the
the original
their farmland
parking lot

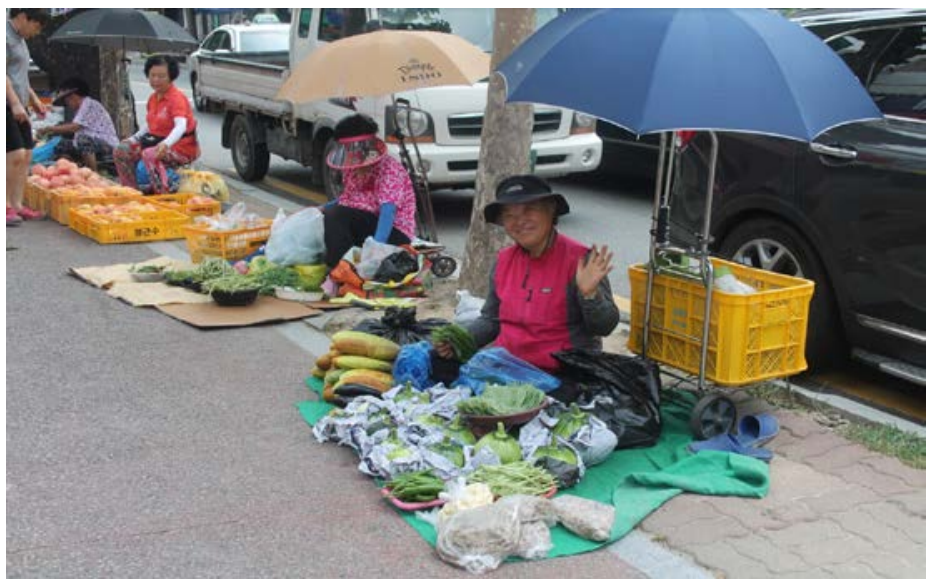
farm next to
According to
participants,
purpose of
was to build a
owned by the
University
Figure 14 Seller Kim(65) in Samchun market
(figure 15).
But until the parking lot is built, the land owners either leased the vacant land out for farming or let the farmers grow their food without permission. Although both farmers Kim and Song provided me with consistent answers on what the land was supposed to function as, they weren't able to give me the source of their information and told me that they somehow 'heard' from 'someone' about the original purpose of the land. Both 


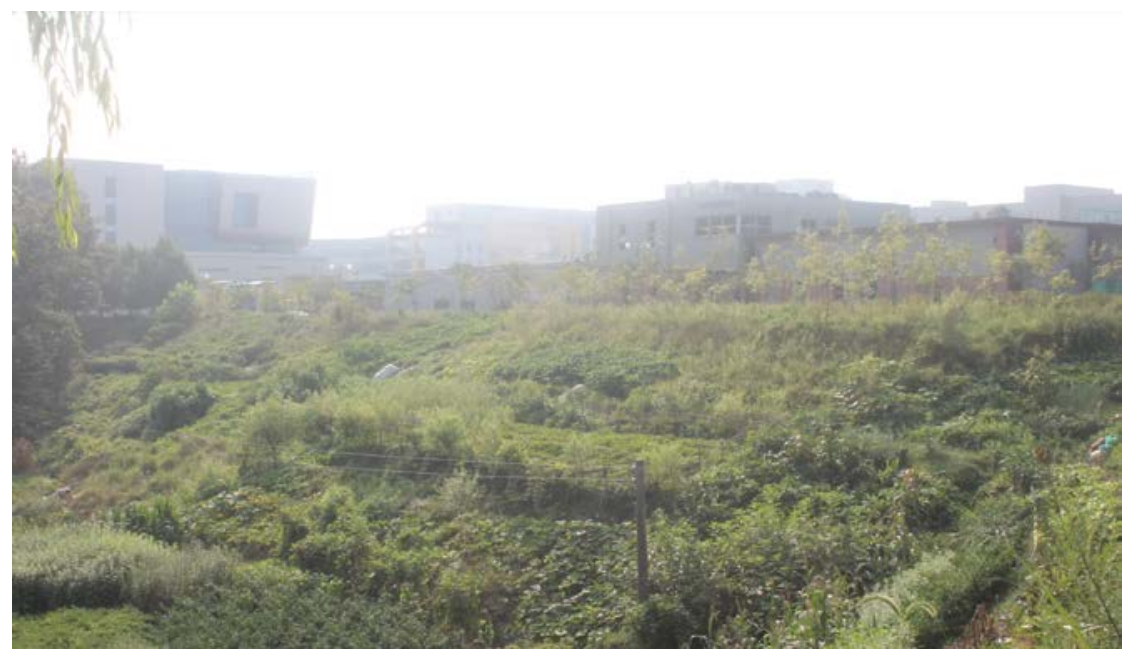

informal farmers

from university area,

Kim, age 67 and

Song, age 60 have

concluded that the

pre-existing condition

Figure 15 land around Chonbuk National University

of the land was not in

a good shape, saying that it used to be very filthy and was filled with swamps and that it's

better used as a farmland, for the purpose of a more aesthetically pleasing and efficient

usage of land. Their arguments justify the reasons on their illegal-ness of the farming in a

vacant land which also justifies the informal conservation easement of the land from the

land owners, making it reasonable for them to follow the rules of the informality. Both

Kim and Song's farming is all informally structured, from land obtaining process to an

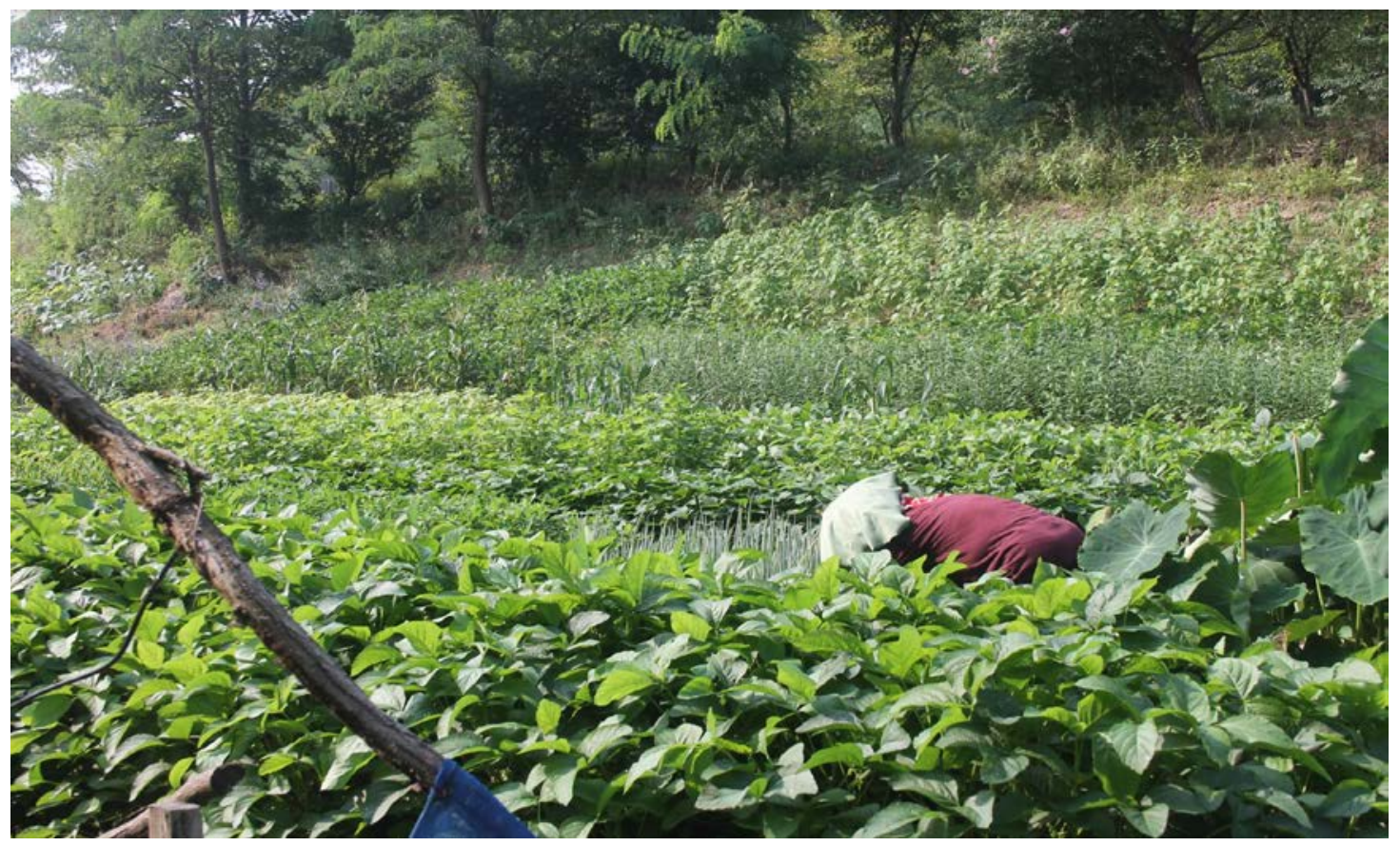

Figure 16 Farmer Kim(67) harvesting from her farmland around Chonbuk University 


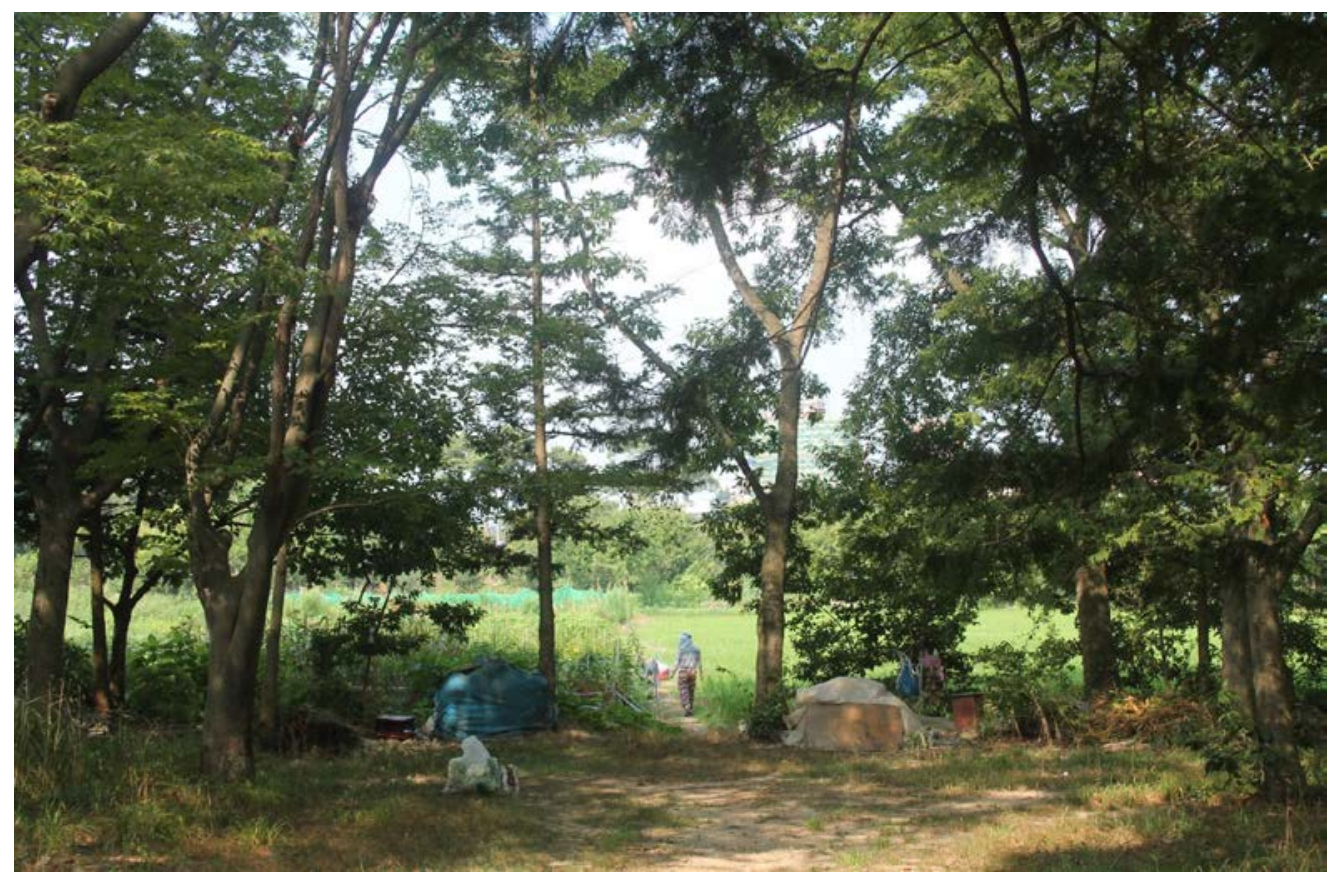

Figure 17 Farmer Song(60) walking into her farmland around Chonbuk University

actual process of farming. This nature of informal farming prevented farmers to give me an exact quantity of their data or any of the legal processes on obtaining the land, land use regulation or the zoning ordinance. For example, farmer Kim, age 67, decided to farm since she wanted to grow her food on her free time and found the deal through her friend who works as a broker that leases out the land informally. She said that she pays about 150USD for however long she wants to farm and also mentioned that the broker who introduced her to this land was actually one of her husband's friend, which is why the broker gave it to her for a cheaper price. Kim had an assumption that the broker can charge as much as 200USD to other people, but again, failed to tell me the exact rental fees. This informal easement of the land serves the purpose of the land differently with no set contract. The city does not recognize the leasing process and the leasing process of the land is entirely done based on community members' relationships and trust in between the broker, the owner and the farmer. Tree farmer Kim, age 47, who grows trees around Mt.Gunji also said in his interview that he is farming in a privately owned land that he leases and that "The land is 
leased for 90USD per 330 squares meter. I pay a yearly fee to the owners.” When I asked if he signs any type of contract, he said that he signs an unofficial contract but it is not an official document that is kept in the local government office. Through flexibility and informality of the land-leasing process, a social capital inside the city is created, based on both the farmer's and the landowner's oath on 'I will pay you' which builds a community trust that is followed as a rule.

\subsection{Formality will enhance informality}

While informality seems to be a counteractive concept of formality in a regulatory framework, these two concepts seem to be in harmony with each other that enhances Jeonju's food system. When I asked farmer Song whether she is restricted from the regulatory committee members of her farming rights,

I heard that that land is a privately owned land. But I have grown my food here for 5-6 years. Farming here might be illegal, but no one mentions anything about it. I do not know when the parking lot is going to be built. But I think the parking lot is going to be built soon since there are red lines around the trees here. I think that is a sign that warns us that we need to clear out the land from the local government officials. But we would know for sure that we need to clear out the land if there is a notice saying that "you cannot cultivate here" signs attached on trees. So they let us know in advance. As far as I know, if there is a sign to forbid cultivation, that means the land is going to be developed, so I figured that before that signs show up, I can probably grow my food. - Song, age 60

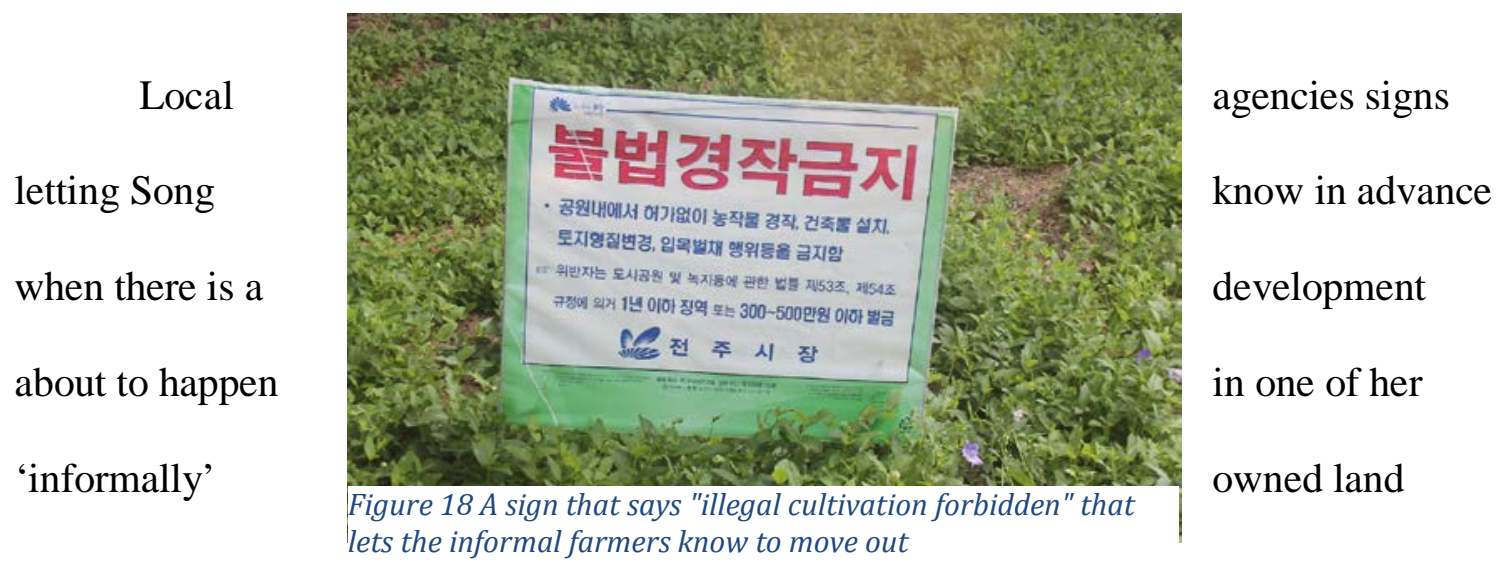


shows a good example of what kind of flexibility is allowed for informal farmers in Jeonju. In this case, the story of whether this land can be built as a parking lot ties back to the ownership of the land. Although Song does not legally own the land, Song's act of growing her food in a vacant land is respected in this scenario. While she has been farming illegally for 5-6 years, none of the local officials nor the residents have restricted her from using the land with different purposes. Instead, the city and residents overpass the illegal usage of the land since it was aesthetically better for the city to allow farmers to grow their food, from the original state of the land that was filled with swamps. Story of Song's informal ownership is an interesting one, for the local government does not acknowledge the land to belong to her legally but somehow passes her rights of farming in a land that nobody acts in. Yet, if the 'real purpose' of the land is about to be utilized, Song is let known in advance by putting the signs around her land (figure 18). Song's informal land usage is an example that sums up the relationship of formal agency and informal actors that recognize each other with equal power and rights for the food production process.

The aid from higher structures in the local government agency is well shown in the food market as well. When I asked the seller in the Samchun market if there are any restrictions on their act of selling in the sidewalk, Seller Kim mentioned that 'the local government' of Jeonju allows them to come out starting from 3:00PM. The sellers in the market did not know much about how the regulatory process worked so I asked the city government official on the issue of regulation. Location of my two research sites were both located in Wansan-gu in Jeonju, which meant that I had to talk to an urban planning team in Wansan-gu government, a lower district gu government within the city 
government agency of Jeonju. Traffic Economy team under Wansan-gu government was in charge of regulation of street vendors. When asked if there were regulations or policies that restricted for the sellers, Taemin Oh, a team leader of the Lateral Maintenance team responded by saying that there is an ‘informal regulation’ placed on the street vendors. However, this regulation is not heavily placed due to an informal policy that supports the 'small merchants' livelihood' in Jeonju street food markets. Although no official records exist and are kept in a government agency, Oh showed me a page of the 'Status of Street Vendor Provisional Allowance Area' (appendix 2). Many of the locations of the street market sites around Jeonju were appointed that was created for the reasons of 'protection of livelihood of small merchants' and 'providing convenience for the local residents that lack in food markets around their residential area'. According to the allowance time listed on the sheet, Samchun market, created in the year of 1992, contains about 155 vendors and allowed to sell from 4:00PM to 10:00 PM daily and from 10:00 AM to 10:00PM on weekends. I asked if there are any consequences for the merchants who do not follow the 'allowance time' and Oh said that there will sometimes be a watchman who gives those merchants warnings.

In the Status of Street Vendor Provisional Allowance Area, informal cubby stores in Nambu market is also listed as well. When asked how they settled down on selling in these cubbies near the river, Seller Park in Nambu market responded, "All these cubbies were built by the city. We don't have to pay the rental fee to the city government, but we do pay for the electricity. My cubby is \#77 and it was built in the year of 2000 June. We 
have a lease contract that we need to sign with Wansan-gu.” (figure 19). Park also mentioned that she used to be an informal seller who started selling bean sprouts that she grew where her cubby currently exists. However, after she got her cubbies, she started to
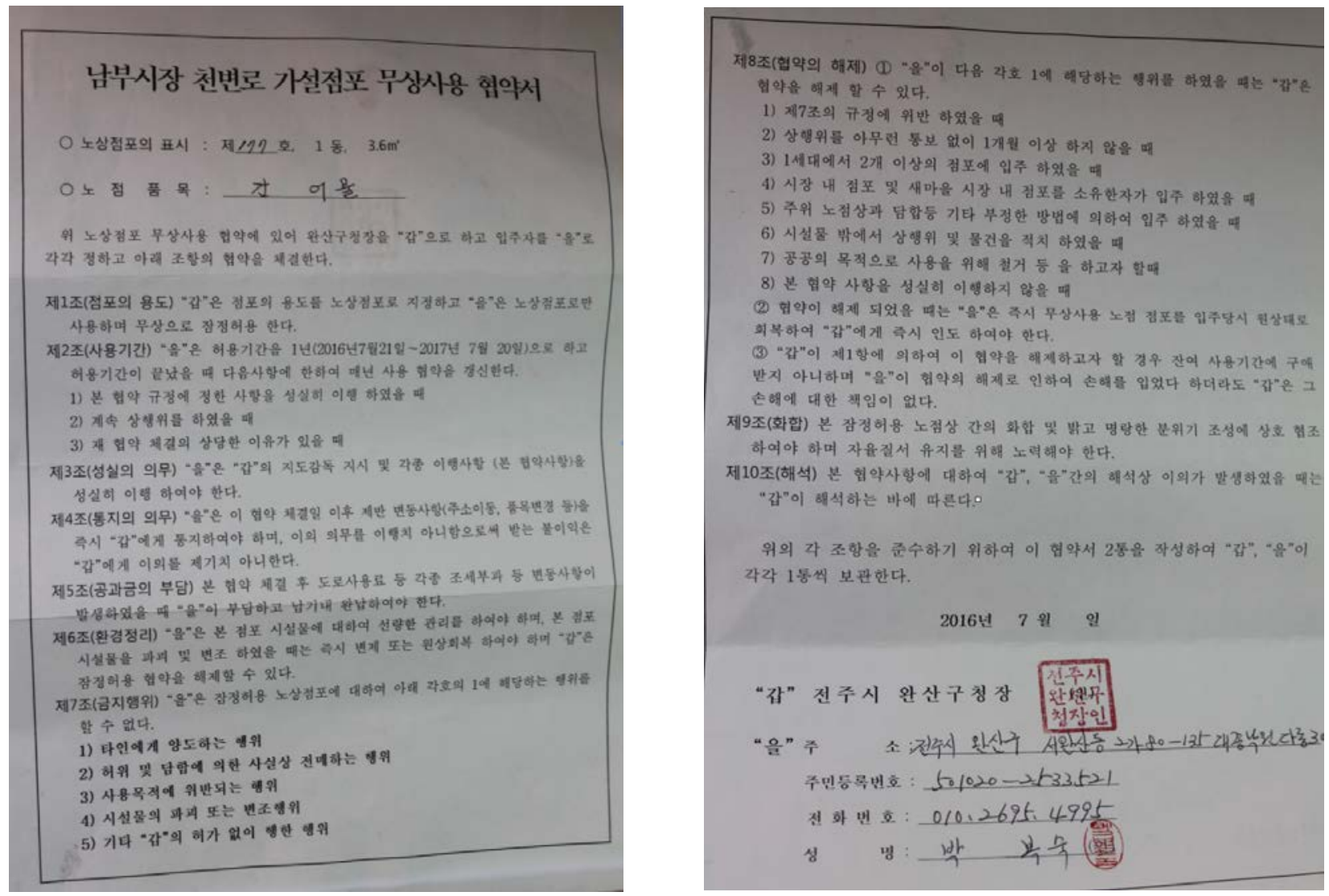

Figure 19 Nambu market vendor cubby contract signed by seller Park(69)

take her business more professionally as a middleman, getting dried seafood from other merchants from different areas and selling them. When I contacted the government official member Hyekyung Jang in a Conventional Market team of Transportation Economic team in Jeonju City government, Hyekyung provided me with a another info sheet specifically talking about cubbies inside Nambu market (appendix 2). According to the data sheet, Nambu market was built in the year of 2001 and contains 188 street vendor cubbies. There are some rules that are applied in these cubbies. All sellers have to renew their lease every year in the beginning of July and cannot occupy more than one 
cubby at a time. Jang, as with the same reasons that Oh from Wansan-gu government said, also remarked that these cubbies were built to support small food merchants and was a necessary step to give proper infrastructures to the informal food merchants and the support of traditional market. Both the sellers and the local government officials have mentioned that the support of an informal food business system comes from cooperation with governmental infrastructure gives support for the informal selling of food with the respect given to these small time merchants. However, when I asked for any reference of formal documents, Jang has mentioned that there are no formal documents kept, since once it becomes formally documented, it abides the code of the sidewalk and defeats the original purpose of the sidewalk. The key point in aiding these informal merchants was to provide a flexibility in policies and regulations by respecting the nature of informality. Now with a proper infrastructure built for the market, Nambu market has developed into a larger food market that provides a more structured platform for both local residents and informal sellers.

Another policy example that shows the support of local food system in Korea is found in a small county town called Wanju, geographically located right next to Jeonju. Wanju is researched as a platform place that supports local food, and its strategy analysis is divided into three management parts where Wanju's local food platform is described as a "space where a basis of public activity, negotiated rules, structures, and interactions take place.” ${ }^{66}$ Whilst Cho identifies the strategies and problems facing the Wanju-gun local food station as a medium for local food movement, Cho argues the platform model of Wanju-gun reveals the public properties of basic visions such as the vitalization of the

66 Cho, Eunjin, and Jong Oh Lee. 2014. "Local Food Station Of Wanju-Gun As A Platform". Advanced Science and Technology Letters 52 : 153-159. 
area, the convergence of a variety of subjects, networking, and efforts for societal satisfaction which closes gap between producers and consumers. Wanju county's current strategies include providing social community space on blogs or websites, stocking infosheets and pamphlets for people who are not familiar with computers, giving consumers the opportunity to participate in Wanju local food events, Wanju local food markets and the Wild Food Festival. Such strategies aggressively utilize the complex local food cultural space. Wanju, at the very least region wise, is well known advertised for its local food, and it is the county government that is providing a platform for this opportunity. With many of the residents being farmers, it can be concluded that the formal institution of Wanju has helped promoting the local food system in the community.

Contrary to the case of Wanju-gun, a direct engagement platform for local food in U.S., such as farmer's market is not always supported to its full extent. For example, farmer's markets in U.S.'s profits, made from direct economic exchange is not recognized as what they can get away with for free and is not supported for taxexemption. For example, Virginia's tax exempt on non-profit organizations are commonly called a 501(c)(3) and according to IRS, private interests that create individual profit is not recognized for tax-exemption. ${ }^{67}$ Having a more structured process that does not recognize the platform for direct exchange of local food can lead to a vast difference in how these markets function which might lead to a potential obstacle in supporting and participating in local food system.

By conducting a qualitative analysis of gathering information on the nature of informality inside street vendors and informal farming, I was able to evaluate the key

67 "Private Letter Ruling 200818028 ". irs.gov. N.p., 2008. Web. 29 Apr. 2017. 
points that exist within the local scale of informal food system in Jeonju. It seemed so that there are rules followed within the informality such as the concept of business ethics and formation of union between the sellers. These rules and values of an informal system are promoted by a higher formal institution by providing a flexibility in regulatory system of the informal business. By aiding these small-scale food merchants, government officials were able to provide convenience for the local residents and acknowledged the culture of informal food system in Jeonju. The where and how's of an informal food system comes from a historical and cultural background stories of the urban space and recognizing this allows the community residents to benefit from the socio-cultural benefits by engaging in local food system. A flexibility in a food system policy enables the local residents of Jeonju to connect better with other participants that produce social capital in the city space.

\section{Ch.4 Socio-Cultural benefits of food system in Jeonju}

In the global context, food has been central to the life of every individual due to its' complex connection with human nourishment and comfort. What we eat, how we produce and distribute our food, who prepares it and how we think about it as traditional or modern, local or national are in a constant state of change, affected by the state of history and culture. Everything that has to do with food from capture, cultivation, preparation to consumption is strongly tied to the bonding of a community as well as formation of the cultural act. Likewise, food producing and eating reflects on the micro level the consequences of macro level of socio-cultural benefits in one's country. This chapter focuses on the economic activity between the merchant and the customer and 
how their friendship-like relationship plays a role in connecting community members. I also analyze the social status of the local food system participants and their perception of farming which is closely related to the quality of their life in the city.

\subsection{Connected Lives}

Viviana Zelizer, in her book The Purchase of Intimacy, argues that people who blend intimacy and economic activity are actively engaged in constructing and negotiating 'Connected Lives'. ${ }^{68}$ She argues that this form of the connected lives is often undermined and is controversial by separating the economic activity and the intimacy. She gives out an example that shows "how regularly intimate social transactions coexist with monetary transactions: parents pay nannies or child-care workers to tend their children and how their parents give their children allowances, etc." ${ }^{69}$ Economic activity and intimacy is also prominent in the market as well, where over time, some entrepreneurs develop close relationships with specific customers, establishing a constrained form of friendship or 'commercial friendship'. ${ }^{70}$ These economical acts associated with the social bonding are also observed in Korean dynamics as well, which results in a cultural impact in society. For example, all the buyers in local food market system all mention the recurring themes of social interaction and economic exchange. When asked the question reasons on why shopping in Samchun market, Yoo, age 75 responded,

I don't really see the point of going to a large supermarket. The food is cheaper in the streets and it's more convenient for me to go since I live right next to it. One of

\footnotetext{
${ }^{68}$ Zelizer, Viviana A. The Purchase Of Intimacy. 1st ed. Princeton: Princeton University Press, 2008. Print.

${ }^{69}$ Ibid. 27.

70 Ibid.
} 
the good things about street market is that I like to strike a conversation with some of the farmers/merchants and that is always a highlight of my grocery shopping. There are couple sellers that always come out daily. Sometimes I just go out to take a walk. These sellers who know me, they give me more for the same price or sell food to me for cheaper prices. I usually get vegetables from them.

I like buying food from an informal market in addition to traditional markets because there is a good relationship built in between me and the seller. I know that fruits such as peaches and watermelons are cheaper and better quality to get it in the street market. I am a regular customer of this lady who sells kimchi, so she knows who I am and always give a lot more for the same price. I really enjoy the idea of bonding over food. Buying food from the street market is more than just exchanging money, it is about us socializing and bonding. I like street markets more than large corporate-owned supermarkets. We are paying for the brand value in those supermarkets. When I shop at markets in a street, buying food feels real, with real interactions, but when I'm buying food from the supermarket, it feels as if I'm paying for my food forcefully. I don't like the feeling that I get when I walk inside the large corporate owned supermarket -Chung, age 26

Although not conceptualized, both interviewees' interactions with sellers in an informal sidewalk street food market has been a positive one, one that emphasizes economic efficiency based off on their friendship with the sellers. Both of them mentions about how the food is 'cheaper' and how they are 'regular' customers of a certain seller in the market. Chung reflects his experience of shopping directly with the seller as 'real' compared to the grabbing groceries from large supermarkets. Chung's experience of getting food while engaging in a communication with the seller is more meaningful and rewarding. As he develops a friendship with the seller, he is able to connect with the seller on personal level, which enhances the positive experience that he gets from an informal economic exchange.

Although it has a more formalized infrastructures, similar interactions can be found in Nambu market as well. Nambu market shopper, Kim, age 56, responded saying I like the atmosphere of Nambu market. I think there are many pros of shopping in traditional markets like this. First of all, I pay way less for the same amount of food or get more amount of food here. I would say that food that is sold in Nambu market 
is 3-4 times cheaper than the food that I get in supermarkets. I also barter with the sellers here and most of the times the sellers give me more food. I don't find shopping in this type of market difficult at all. I actually feel a lot better when I buy food that is displayed and that is not wrapped up in plastic sheets and boxes. I like going and observing how food is displayed outside. I also don't feel like it's a waste to waste all that plastic sheets and boxes. A lot of the food comes from the farmers who's also growing it, so I believe it's more fresh produce.

The interaction of both the sellers and buyers is also noted during the observation of both Samchun market and Nambu market. Some of the main observation points that I have observed were : 1)customers and sellers having a friendly greeting 2) buyers and sellers having a conversation of 'what's freshly picked and available today’ 3) sellers asking personal questions such as family and friend issues and sharing their personal stories 4) buyers bargaining the price for the food, urging sellers to give it for a cheaper price 5) sellers trying to talk buyers into buying their food products with loud call outs of advertising their food and 6) sellers communicating with other sellers on how their business is and asking each other personal questions. All of these acts of engagement inside the street market shows how each community members interact and bond with each other over the economic exchange of food supplies. The development of a community member relationship is enhanced in the process of direct buying and selling, and having an informal structure of local market system has given the opportunities for participants to build a friendship between the community members. These local food markets in Jeonju are the platform space that create a hub of social interaction where the community relationship can flourish.

\subsection{Flexibility of Economic Exchange}


Another theme that is often mentioned from interviewees was the price of the food and how cheap the food from local food market is compared to the food sold in corporate owned supermarkets. All of the buyers' impression of cheaper food price is also a result from a more direct relationship with the seller inside the market which is only possible in a local scale. All three buyers mention the concept of 'bargaining the food price' is possible or that they can get more food for the same price. This is an example that shows a flexibility which is allowed in a direct engagement system in a local food market. The price of the food, as well as the quantity is completely dependent on the seller and how they manage to sell gives more flexibility in the food price. For this reason, shoppers have a more positive perception of buying food from the food market rather than to shop in the corporate owned supermarkets.

Sellers are also very well aware of how the economic exchange in this kind of market system works. When I asked the question of what advantage is there in shopping at local food market, all three sellers shared the same answers.

"I like the idea of local food markets like this. Most of the times, there is a communication that happens between the buyer and the seller. Buyers can almost always bargain for cheaper price and also make sure that they can get other food for free."

-Nambu market seller, Sung, age 85

"I like these markets since sellers sell it for a cheaper price. I think it's better for moms to shop here. Why wouldn't you want to save money by paying cheaper price? Customers can also barter and I can give out more food for the price that they pay.”

-Samchun market seller, Kim, age 65

"I know that I also give free giveaways to my customers. We don't have an exact amount of food and the price associated with it, but that is the beauty of these informal markets. We are more generous than cashiers in the supermarket. You can't barter in supermarkets”- Nambu market seller, Park, age 67 


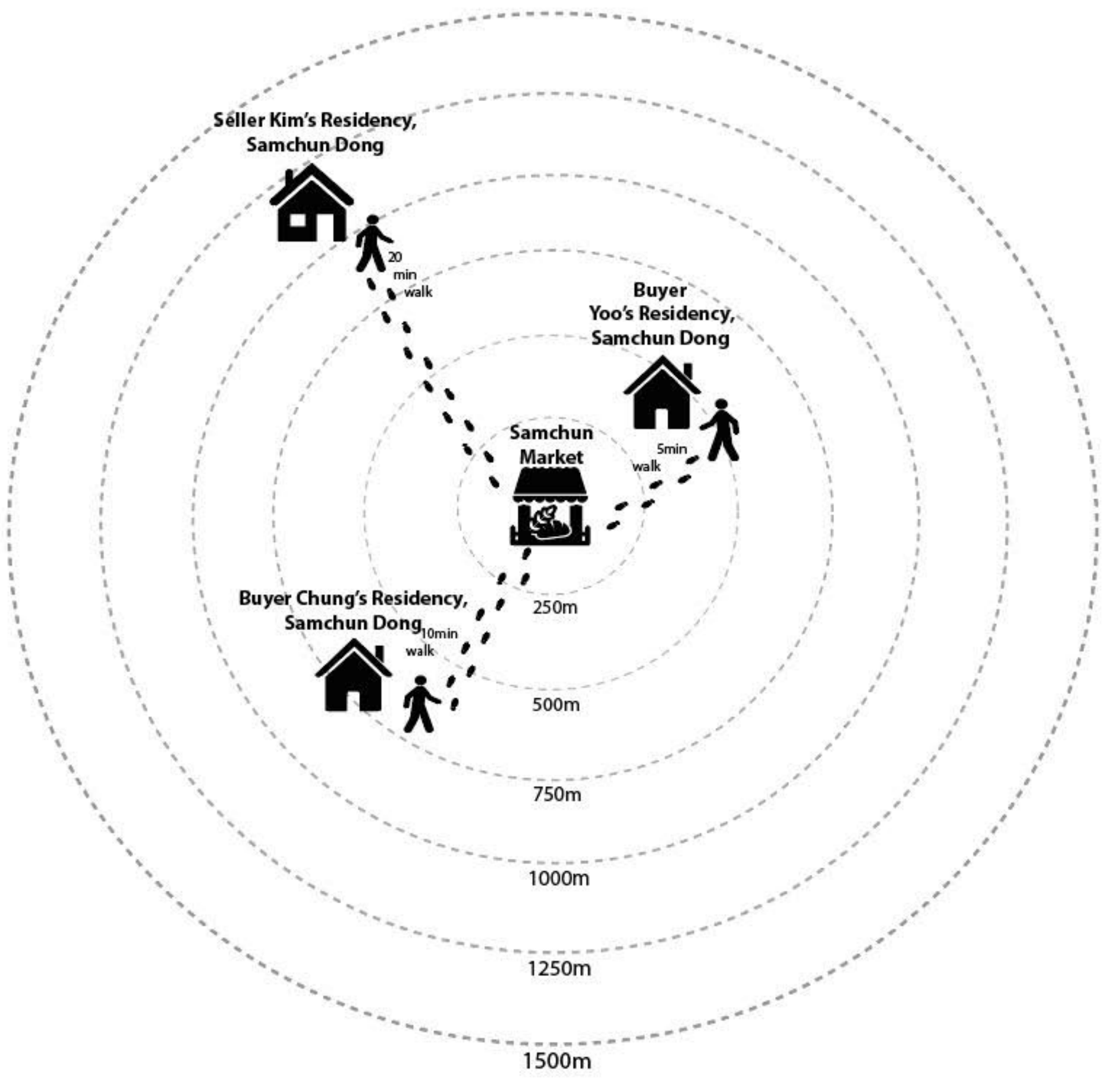

Figure 20 Samchun market participants' travel distance 
The social distance between producers and consumers is abbreviated into direct exchanges in these local food markets. All buyers and sellers' residency from the food market was either in the same dong (neighborhood) or very close in proximity (figure 20, 21)

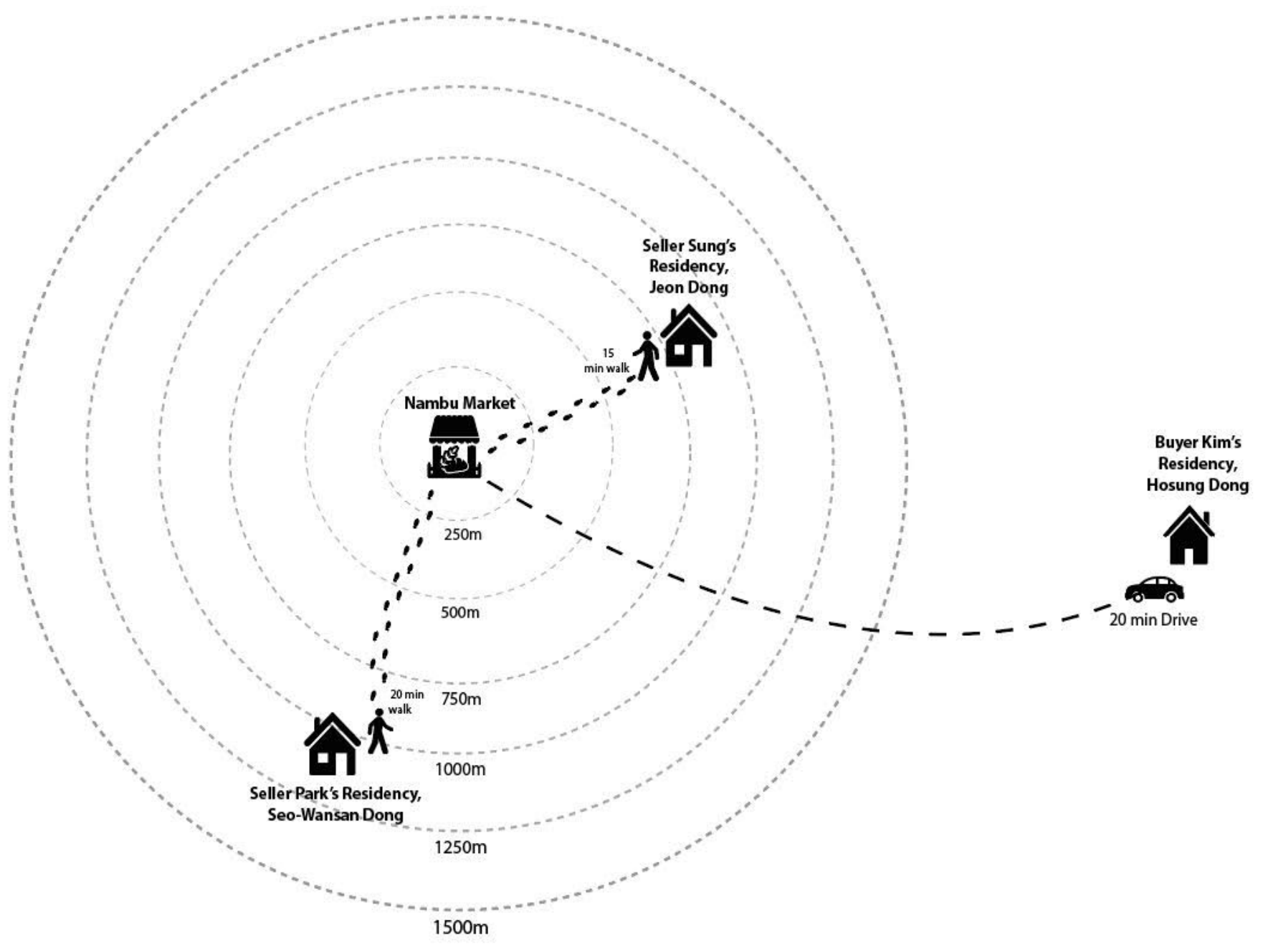

Figure 21 Nambu market participants travel distance

The closeness of the geographical and social distance between the sellers and shoppers enables them to engage in a direct exchange, resulting in a more human-centric engagement and flexibility of the economic exchange of food. 


\subsection{Share-ability + Generosity}

The flexibility of the food system is what allows the concept of 'generosity' of the members in the community to flourish. Almost everyone including sellers, buyers and farmers have mentioned that they share their food with family members and friends. All of the sellers have mentioned that they give out food out for free to their children and grandchildren. For example, seller Park, from Nambu market, specifically mention that

I mostly get dried seafood that was caught locally, since I share all food with my family members and friends. I try to stay away from non-local food and buy all of our groceries here in the market. It's very convenient for me to shop here since it is right here. When my kids need groceries, they call us and order food and we can package and mail it to them.

To her, the food that she sells is the type of food that she shares with her family members. The food that she shares with her family members have to be from 'the local' area which is what is good for her family. The generosity of the food sharing is passed along to her family members, which makes her to be more aware about the food that she is selling on the street. Both seller Kim and Sung also shared the same sentiment on sharing food with their family members. When their kids need groceries, they said that they "buy here and send food to them in Seoul where they reside.” Often times the sellers have mentioned about where their children are residing and it seemed as if that these sellers are sending food to a much more dense cities, like Seoul. The share-ability of food made the food to travel on national level but usually never goes out of the boundary of national-local scale, which to the sellers, is better food that is higher in quality. Park, age 67, a small-scale farmer who grows her food in her church-owned farmland (figure 22, 23, 24) along with other church members, goes even further saying that she never has to buy any vegetables from markets. 


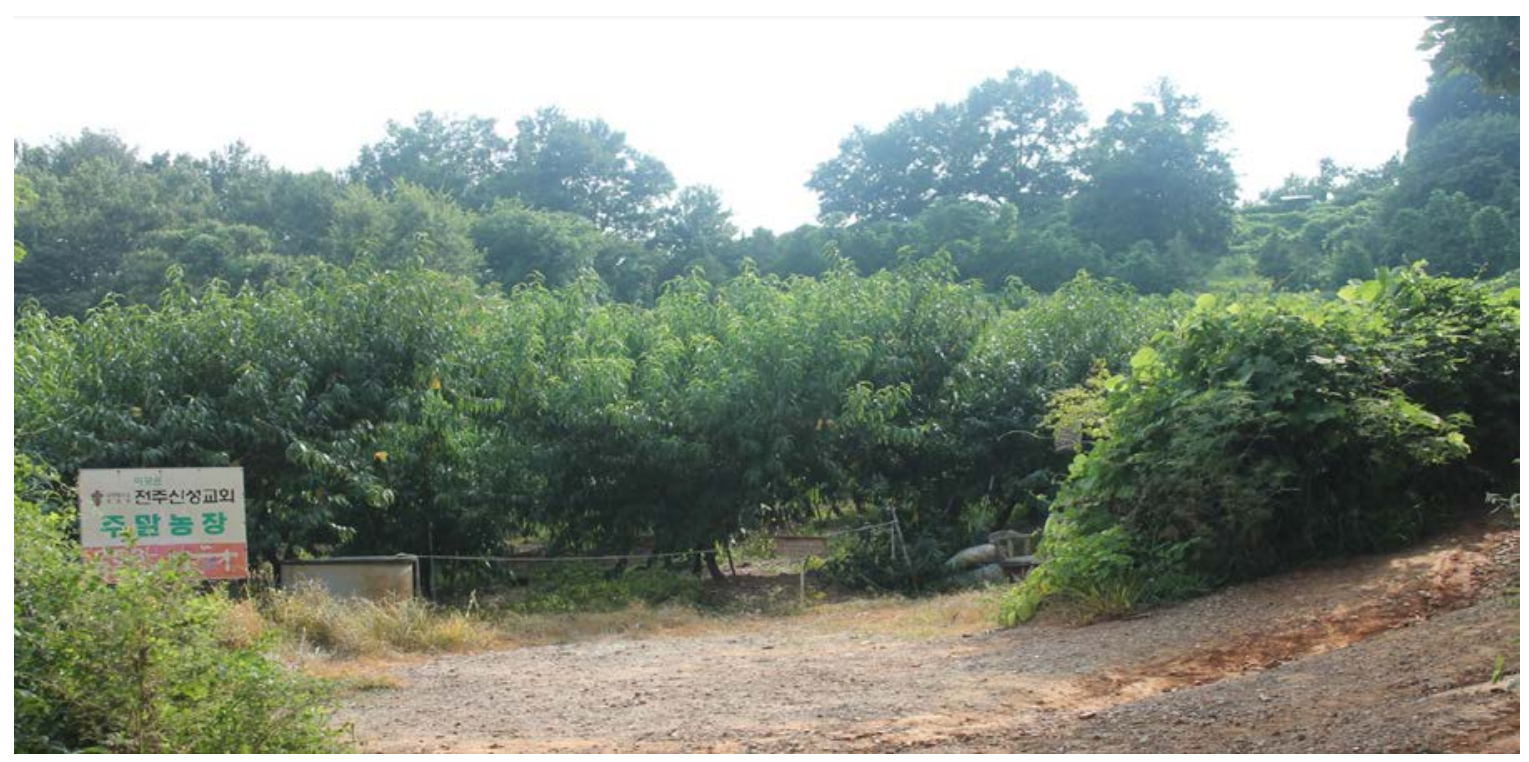

Figure 22 Entrance to the Weekend farm owned by Sin-Sung Church

She said all of her church members grow different vegetables on their farm, so Park ask other church-member farmers if she can just harvest food from their plots and gets all of vegetables from their parcels of farmland. All participants, one way or another share the same value of 'harvesting together' and 'share them' with their community members.

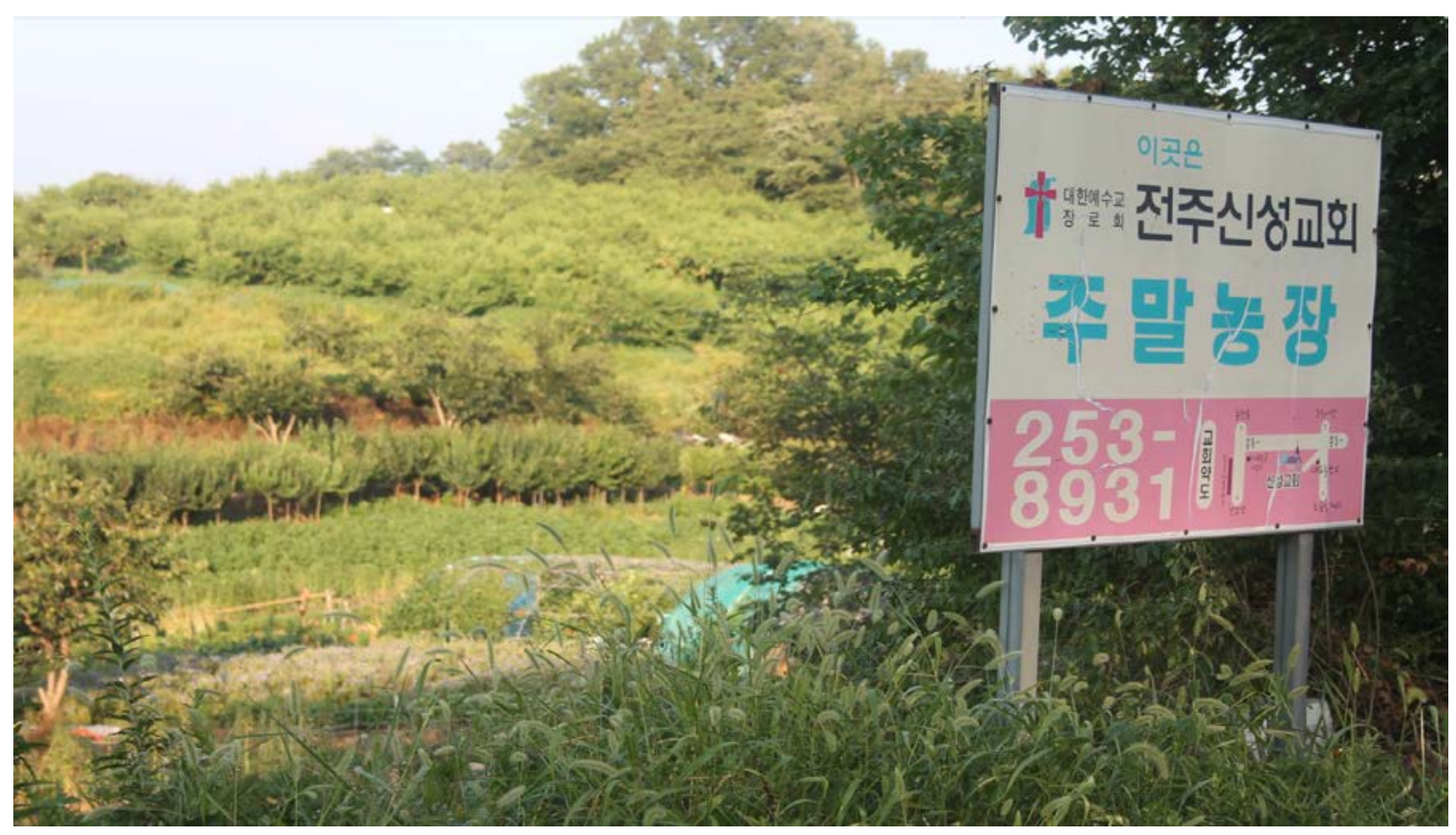

Figure 23 Weekend farm owned by Sin-Sung Church 


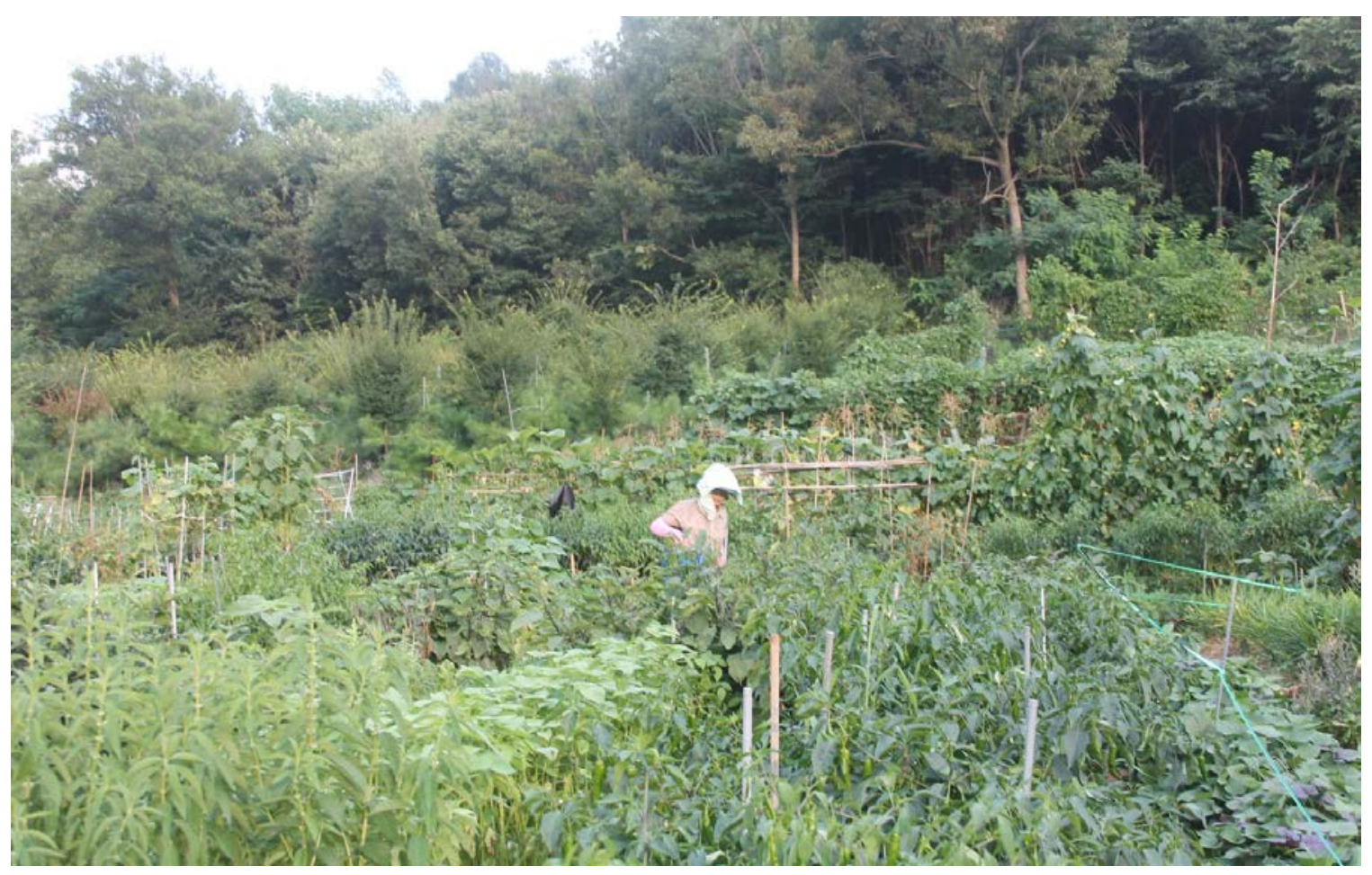

Figure 24 farmer Park(67) working in her church farmland

\subsection{Reflection on Cultural + Social Dynamics}

Food system reflects heavily on South Korea's cultural dynamics such as participants' age that constitutes the agricultural field. All interviewees' ages mentioned, excluding one buyer from Samchun market who shops in local food markets were at the age older than 45 . When asked what their current job occupations were, Kang, age 51, a peach farmer around Mt.Gunji, said that "We all used to have different jobs before farming, but are all retired now. I majored in Chinese and worked in a commerce company. After our retirement, my sister and I decided to inherit the land and work as farmers after our parents.” Similar answers are found within demographics of the all farmers interviewed, since almost all participants have said that they had different jobs before they started farming. Out of six farmers interviewed, three farmers said that they were retired and had 'real' jobs before. Somehow their definition of real work and job was associated with the 'office work' and 
was tied to the age range of 20-40 as well. All participants determined the perception of the age of old vs. young by common occurring themes that were brought up: retirement, farming for hobby, growing food to feed my grandchildren and active lifestyle after the retirement. The age range of participants of the food system was closely related to the age associated with 'old' and 'retirement' in which most of the small scale local farmers started engaging in farming activity once they hit the age of 45 or higher. The age that plays a role in agricultural field is significant in other countries as well, since "ageing population holds potential implications for the agricultural industry, with the average age of farmers thought to be increasing in most Western contexts and estimated to be 59 years of age in the UK." ${ }^{71}$ Reflecting from the interviews of the farmers, farming in local scale associates the activity itself as a type of 'leisure' that one does after their retirement. Interviewees have emphasized that they are not professional farmers and therefore will only farm in smallscale, as a type of activity that they can manage once they are retired. Often times, their perception of professional farming was associated with rigorous and labor-intensive farming and farming in large scale that produces marginal profits. This trend of down-scaling of farming activity as a form of leisure is found even amongst the farmers who called themselves as professional farmers. Seller Kim from Samchun market and farmer Kim (81) from Mt.Gunji also said that they used to be professional farmers that farmed in large scale to make profits. But both of them said that now they are too old and sold most of their land, since their goal was to stay away from strenuous labor of large scale farming but still continue their work as farmers to maintain an active lifestyle. Lobley suggest that the most common form of retirement may not actually be retirement per se,

\footnotetext{
${ }^{71}$ Riley, Mark. 2014. "Still Being The ‘Good Farmer’: (Non-)Retirement And The Preservation Of Farming Identities In Older Age". Sociologia Ruralis 56(1): 96-115.
} 


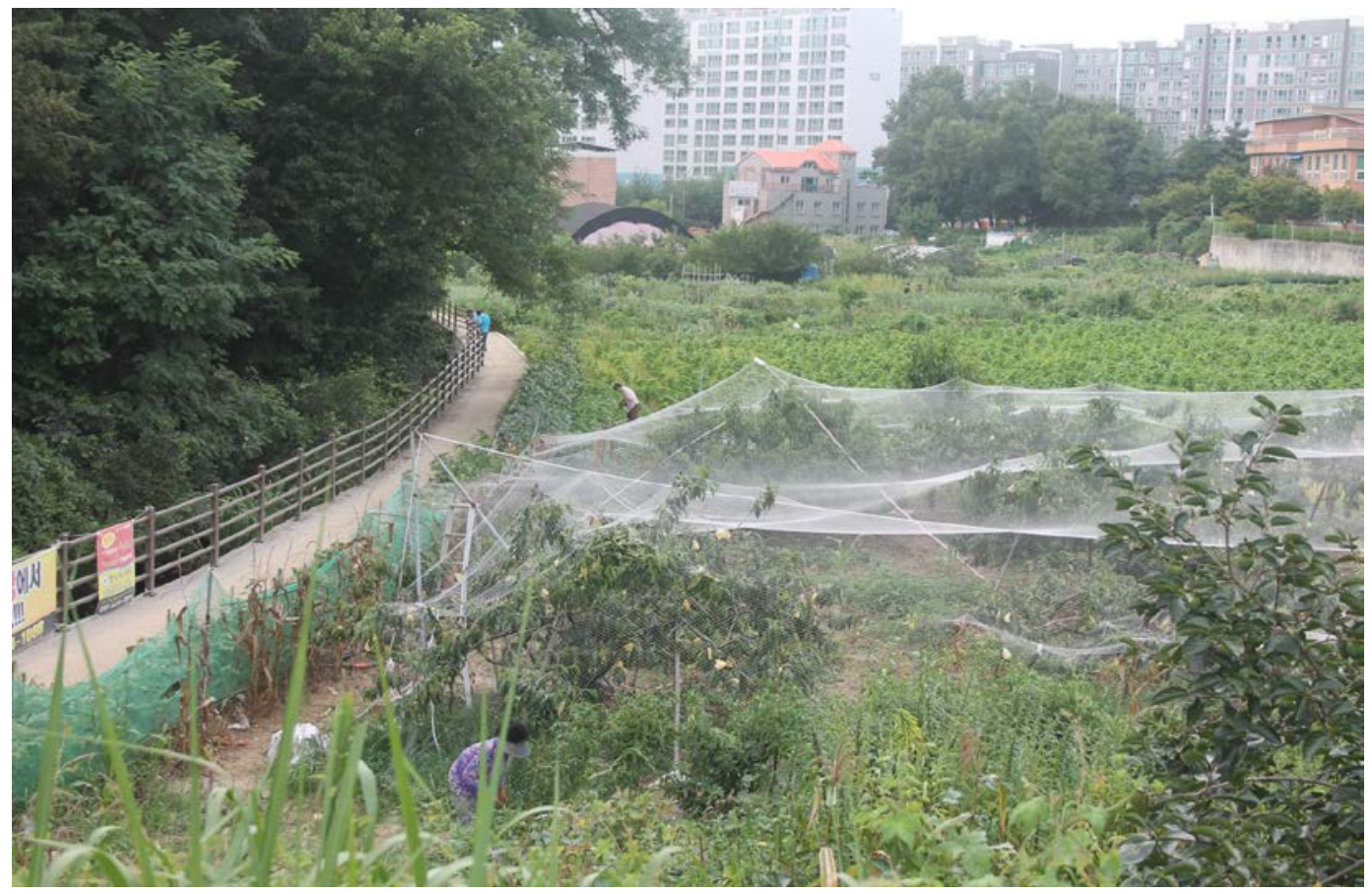

Figure 85 small scale farmland in Mt.gunji

but remaining on the farm in older age, albeit with some reduction in some of the more

arduous tasks associated with the farm."72 Perceptions of these farmers and how they are not the 'real' farmers lead to an informal knowledge of their farming skills as well as the structure of their farm. Most of the farmers that were interviewed could not provide me

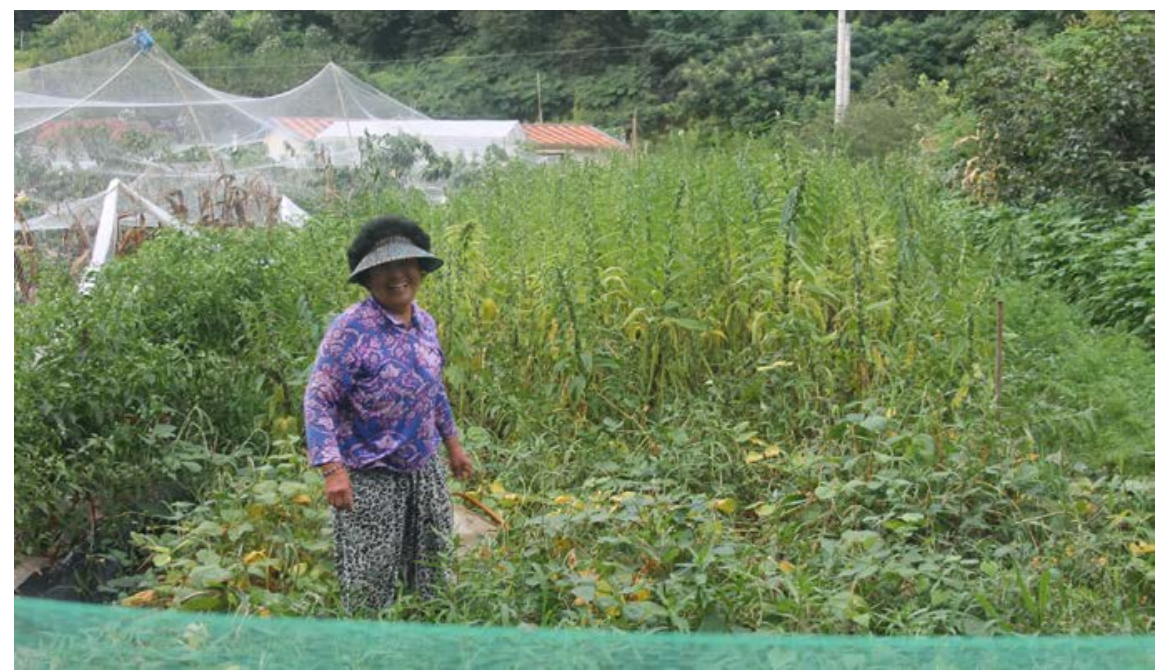

Figure 26 peach farmer Kim(81), in her farmland in Mt.Gunji

the answer of how much land they owned nor the exact address of their farmland.

Farmers that knew exactly how much land they owned were the ones that considered

72 Lobley, M., J.R. Baker and I. Whitehead. 2010. Farm succession and retirement: some international comparisons. Journal of Agriculture, Food Systems, and Community Development. 1 (1): 49-64 
themselves as 'more professional', who participated in a slightly larger scale farming. Those farmers who knew how much land they owned were as following : Kim, a retired farmer who sold a lot of the land after he got old owning 26446 square meters, Kim, a professional tree farmer, a retired businessman owning 8264 square meters and lastly Kang, a peach orchard owner owning 3305 square meters. Farmers listed above were the ones that called themselves 'more professional' in the matrix of the professionalism, but even they indicated about the scale of the farming and mentioned that that they are not the 'true' large scale farmers. Compared to the small scale farmers who did not know how much land they owned or the ones who told me they own 'just couple of plots' of lands, the 'professional' farmers had tangible information about their farms, but all of them still mentioned that they are not trying to make a living out of farming. All farmers have mentioned that their main goal for farming is to provide healthy food for family members and share with their friends. The trend in which all of the farmers who do not seriously count profits from farming explains why they are able to be so generous towards their business as sellers. A cross dynamics of participants' occupation as a seller/farmer in the local food system was common in Jeonju's local food system. Kim, a merchant interviewed from Samchun market sells the excess food that she harvested and Kang (figure 27, 28, 29), who grows peaches in Mt.Gunji also sells leftover peaches on the street around the residential area in Hosung dong. This cross dynamics of a seller/ 
farmer shows a direct relationship of farming and selling of food that is interchangeable in a direct engagement of local food system.

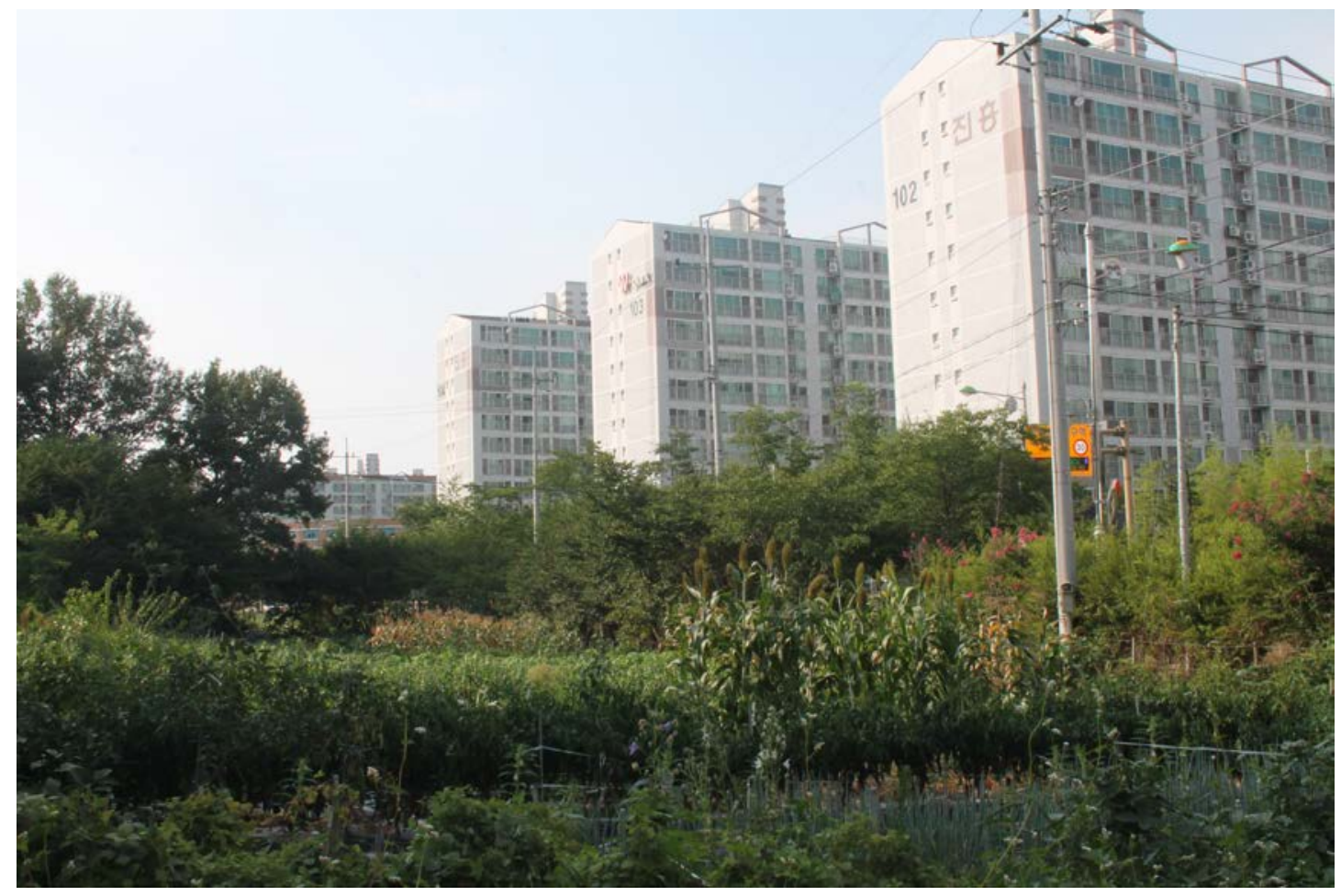

Figure 27 Mt.gunji farms next to residential apartments in Hosung dong

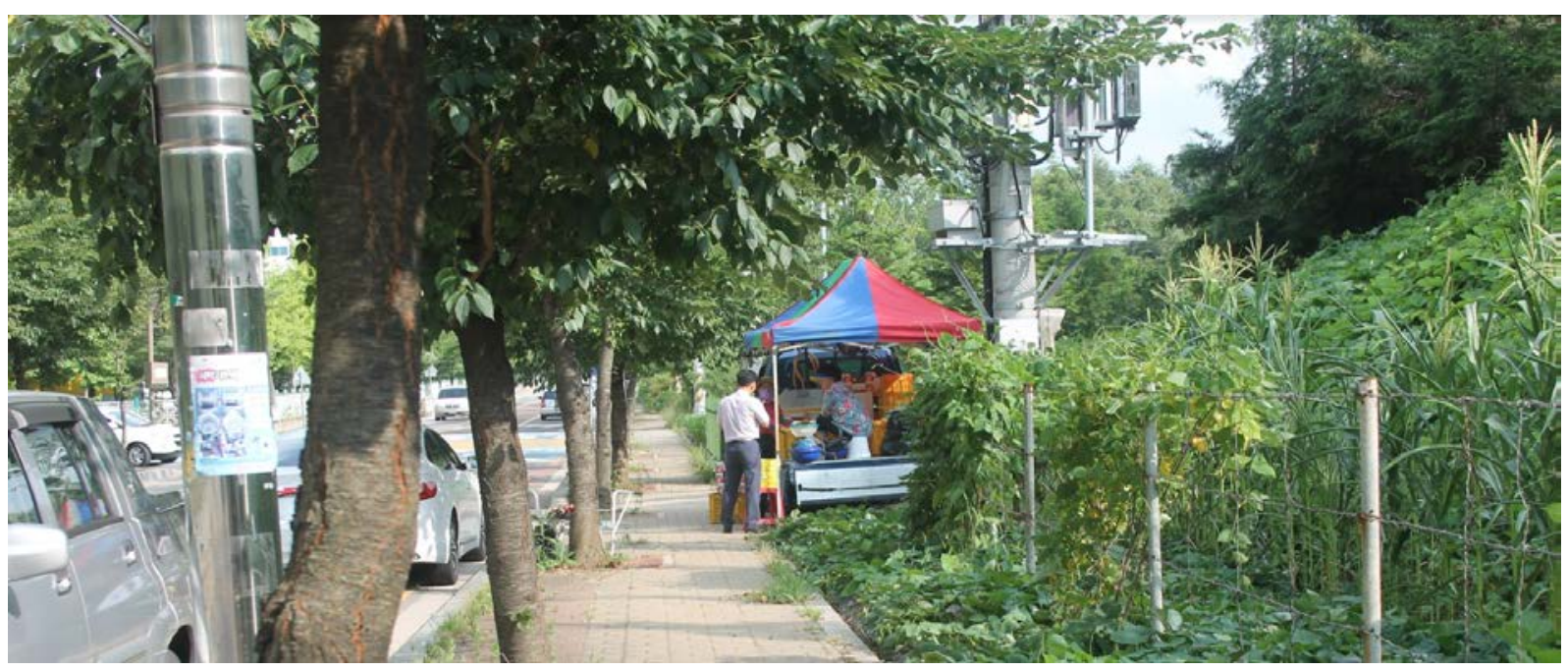

Figure 28 farmer Kang(51)'s informal vendor truck in Hosung dong 


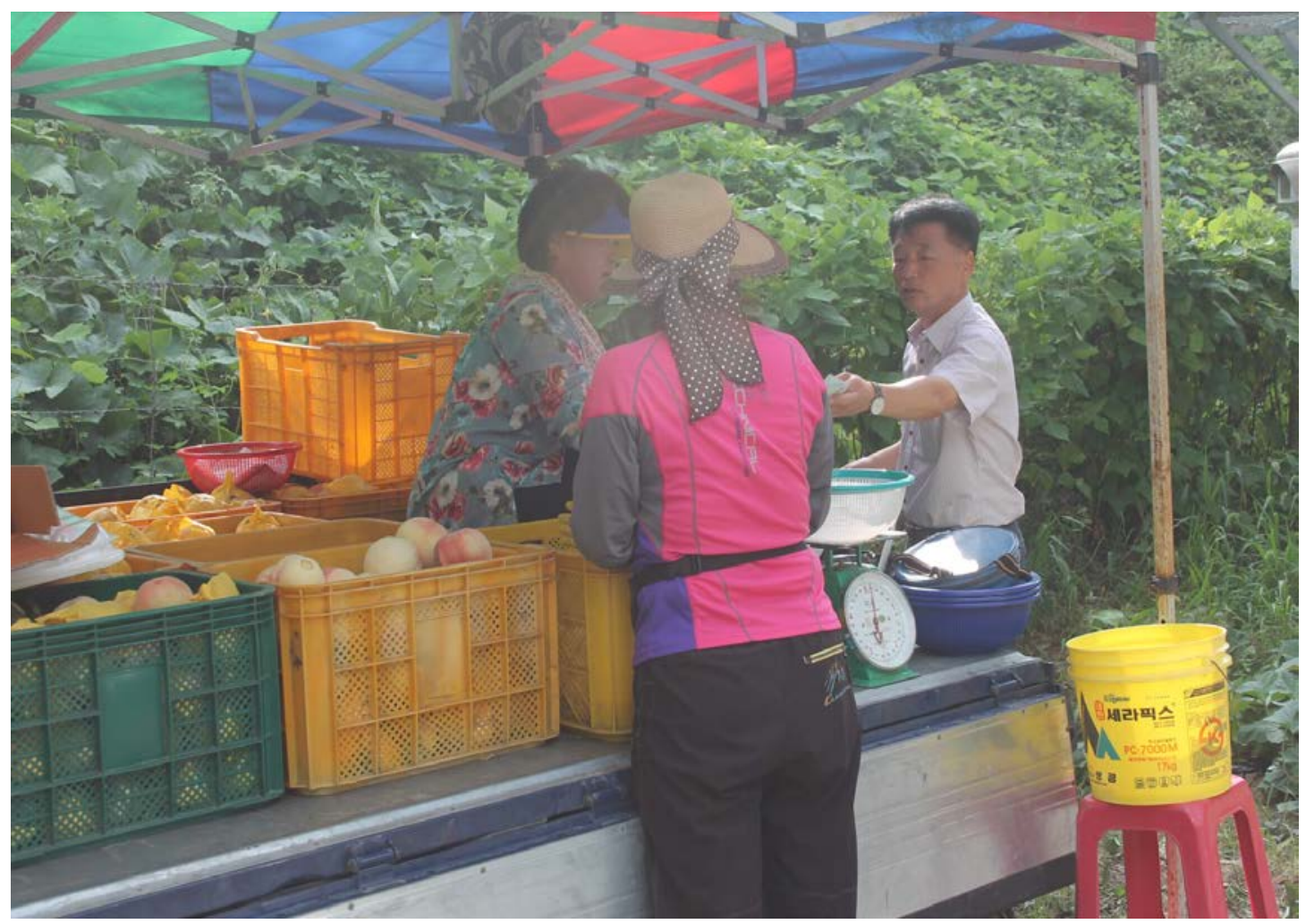

Figure 29 farmer Kang(51) selling peaches

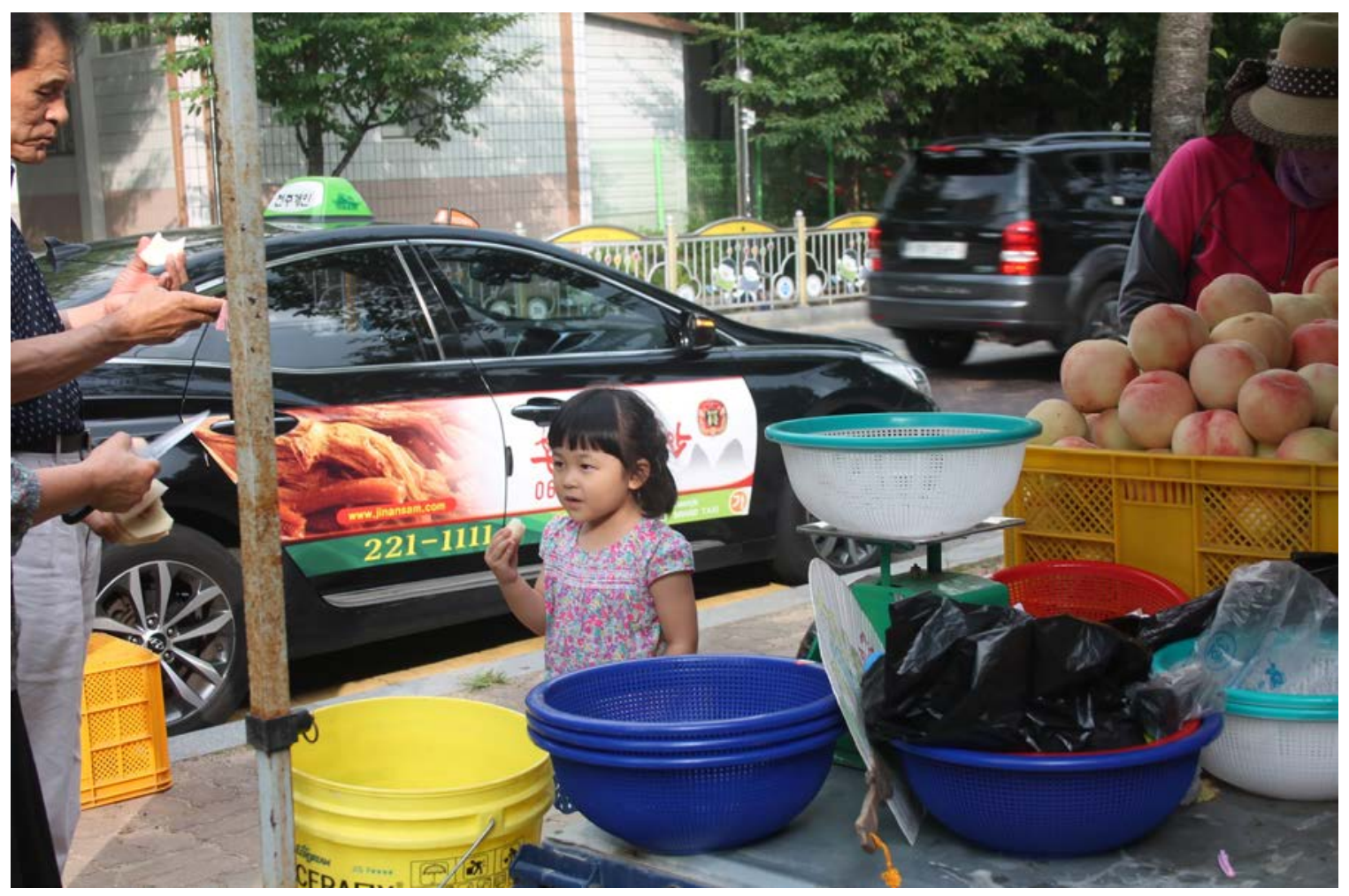

Figure 30 customers tasting peaches from Kang 
Two participants of Jeonju's local food system have also mentioned about the historical context of their own food in their interviews. For example, farmer Kang has mentioned about the 'famous peach' from Jeonju, and said

Did you know that Jeonju is famous for peaches? There is a peach festival that is taking place at the Jeonju stadium. Back in the old days, peach from Jeonju was famous for its sweetness and ripeness that it was even served to the King. To this day Jeonju peach is still well known for its good quality.

This local knowledge of their food was mentioned again later when the buyer Kim from Nambu market mentions about peaches in Jeonju. "I only get Jeonju peaches because growing up, I heard from my parents, peaches from Jeonju are very well known.” This socalled local food knowledge is only mentioned from local residents' mouth to mouth information. There is no documented proof that this famous 'peach' from Jeonju is whether really famous or not, or if it has actually been served to the king before. Although the trustworthiness of this given data is questionable, participants obtained this local knowledge derived from history associated with local food. Kim also mentioned about how she obtained this knowledge from her parents and said she believes it, since her parents are also from Jeonju. To Kim, local food is a symbol of cultural knowledge and space. It is where she used to shop as a kid with her parents and is strongly associated with her cultural background. Her experience of getting local food associates with reflection of her cultural reminiscence.

Based on participants' words and actions, participants engaging in local food system feels the connectedness and stronger bonding with the community members. Both informal and formal local food system and directness of the business, as well as the microscopic scale of farmland created a social space that builds the sense of community. The local food system participants also showed cultural dynamics of Korean agricultural system and its age 
associated with it. Participants in local food system benefitted from socio-cultural benefits of the community residents by engaging in economic trades that serves flexibility in price and share-ability between community members. This type of cultural reflection on small-scale farmers in food system also affiliates with the ecological impact on food system in Jeonju, for small-scale farming results in less food miles travelled and less food waste left over.

\section{Ch. 5 Ecological Impact of Local Food in Korea}

\subsection{What is Local Food in Korea?}

A standard definition of what 'local food' does not yet exist and the term local food remains ambiguous in many cases. The geographical distance between production and consumption can be a determining factor in defining what local food is but geographical distance is understood and discussed in different ways in countries. For example, in the United Kingdom (UK), local food is defined by some as food produced, processed, purchased, and consumed within 30 miles (50 kilometers) of production. In the United States (US), defined in the Food, Conservation, and Energy Act, local food is food that has travelled less than 400 miles from its origin, or within the State in which it is produced. However, considering that South Korea has a small land mass and many mountainous areas, it is very difficult to discuss geographical distance according to the same standard as larger countries like the USA. Therefore, most of the consensus of experts is that less than $100 \mathrm{~km}$ is appropriate for local food in South Korea. ${ }^{73}$

\subsection{Food miles and Waste}

\footnotetext{
73 Chul, JungMan, and David Pearson. 2014. "The Current Status and Potential of Local Food in South Korea." The Australasian-Pacific Journal of Regional Food Studies 4:61-78
} 
According to many authors, "The average item of food on your plate has travelled 1,500 miles.” If one spent any time immersed in local food research, one has repeatedly seen either this number central to discussions of local eating relating back to the concept of food miles, how far food travels en route to your stomach. ${ }^{74}$ In Jeonju, farmers' residencies and distance to their farm is shown in the same or a neighbouring dongs. All of the farmers took their harvest back to their house to their family members which shows the proximity of their food distance. Out of six farmers, three farmers, Park (59), Kim(47) and $\operatorname{Kim}(81)$ were able to go to their farmland by walking, and the rest of the farmers Song(60), Kim (67) and Kang(51) said that they drive for about 10-15 min by car. Although none of the interviewees gave consent out on giving out specific resident addresses, all of them were able to give me information on which dong they reside in. The transportation mode and time of the food traveling back to their family household was very moderate, and was walkable within 20 minutes distance, and almost all farmers supplied most of their vegetables from their own farmland, saying that they try hardest to grow all vegetables or fruits that their family consume. None of them were able to give me the amount of food that they harvest, but said that they grow 'just enough' amount for their small sized families, usually consisted of three to four members. The type of vegetables and food differed on individual bases but many of them overlapped. Some of the food that all farmers mentioned that they grew are: cabbage, pepper, squash, cucumber, pumpkin, sesame, tomato and apples.

\footnotetext{
74 Trivette, Shawn A. 2014. "How Local Is Local? Determining The Boundaries Of Local Food In Practice". Agriculture and Human Values 32(3): 475-490. Web.
} 

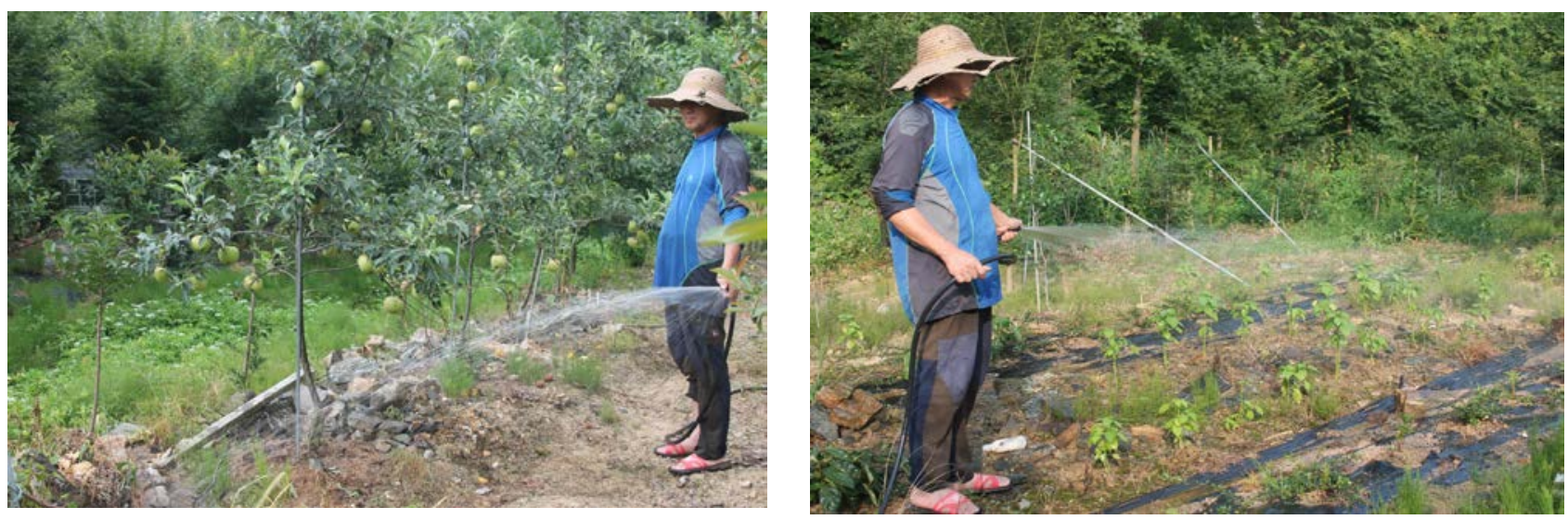

Figure 31 Tree farmer Kim(47) watering his apples and vegetables

Since most of these farmers are farming on a small-scale and did not know exact amount of their harvest, they weren't also clear about how much food excess that they had as well. Often times their answers on food waste were "I grow enough to feed my family, but if there is any excess of food, I just share it with my other family members or friends.” Usually farmers who also works as a seller mentioned that they also sell the leftover as well. For example, seller Kim from Samchun market, who is also a farmer herself said that “farm is small so I don't produce a whole lot, but there's always leftover after I feed my family so I just sell all the leftover in a side market like this.” With the small scale farming, all of the interviewees didn't have an exact sense of the food waste. But farmers' general consensus is that there is not much produce wasted.

Below figure map (figure 32) shows local food system of Jeonju that does not undergo long-range transportation and multiple distribution processes which is consumed locally. This map representation shows how the local food movement minimizes the travel range of foods between producers and consumers, protecting the environment, and 
promoting urban-rural coexistence by developing local agriculture. ${ }^{75}$ Most of the food that is harvested is transported back to the residency of producers in a short distance, not taking more than 20 min of driving, which is also consumed within the approximate distance.

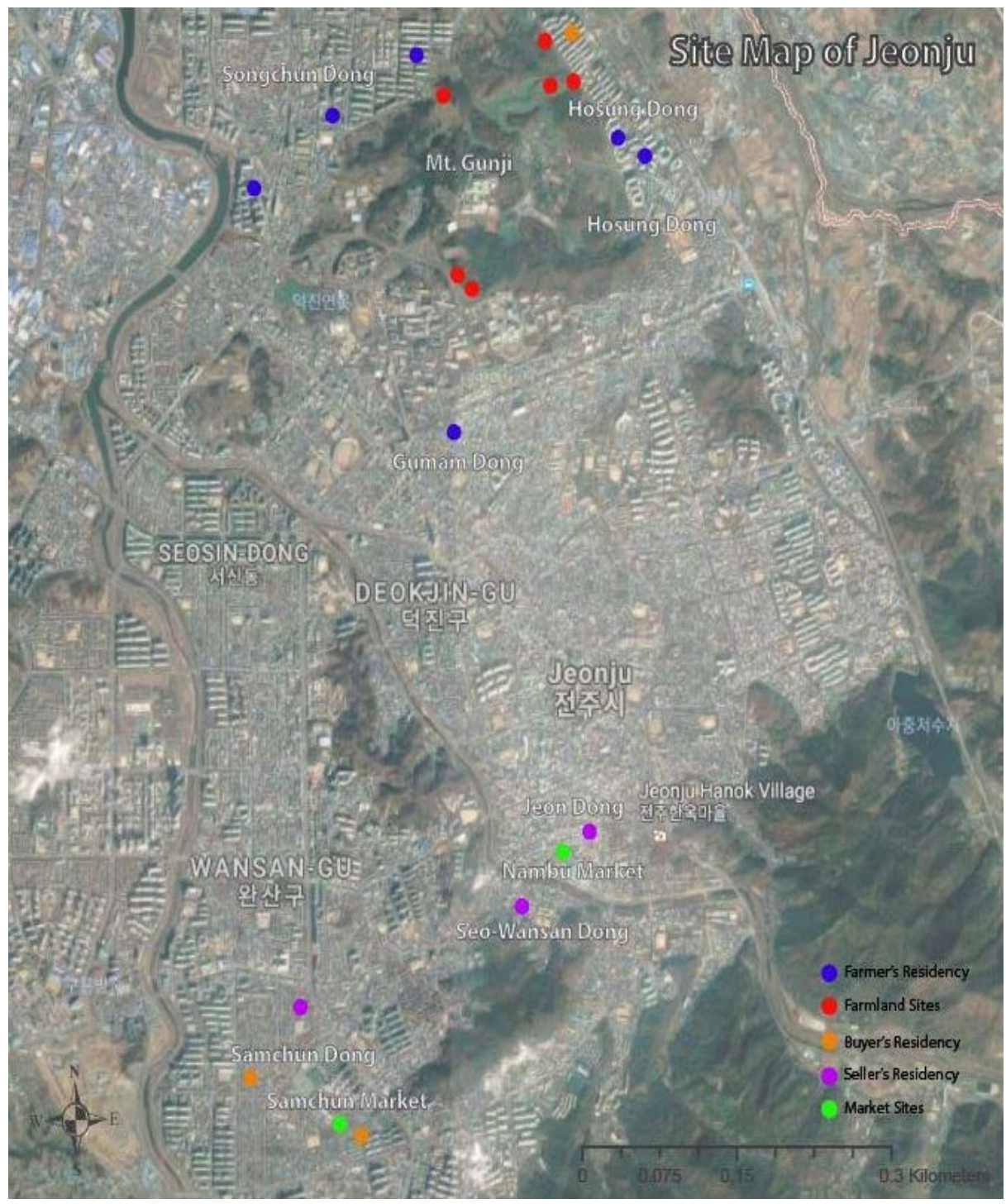

Figure 32 Location of all research sites in Jeonju

${ }^{75}$ Choi, Young-Chool, and Hak-Sil Kim. "Success Factors Of The Local Food Movement And Their Implications: The Case Of Wanju-Gun, Republic Of Korea". Procedia Economics and Finance 23 (2015): 1168-1189. Web. 


\section{3 "Natural Farming is Healthy"}

During the interview process, one common themes that kept appearing from the farmers was the 'quality of food'. I have interviewed four farmers who grew their food in Mt. Gunji, an area zoned for a Nature Preserve and two farmers from small parcels of land next to Chonbuk National University (figure 33).

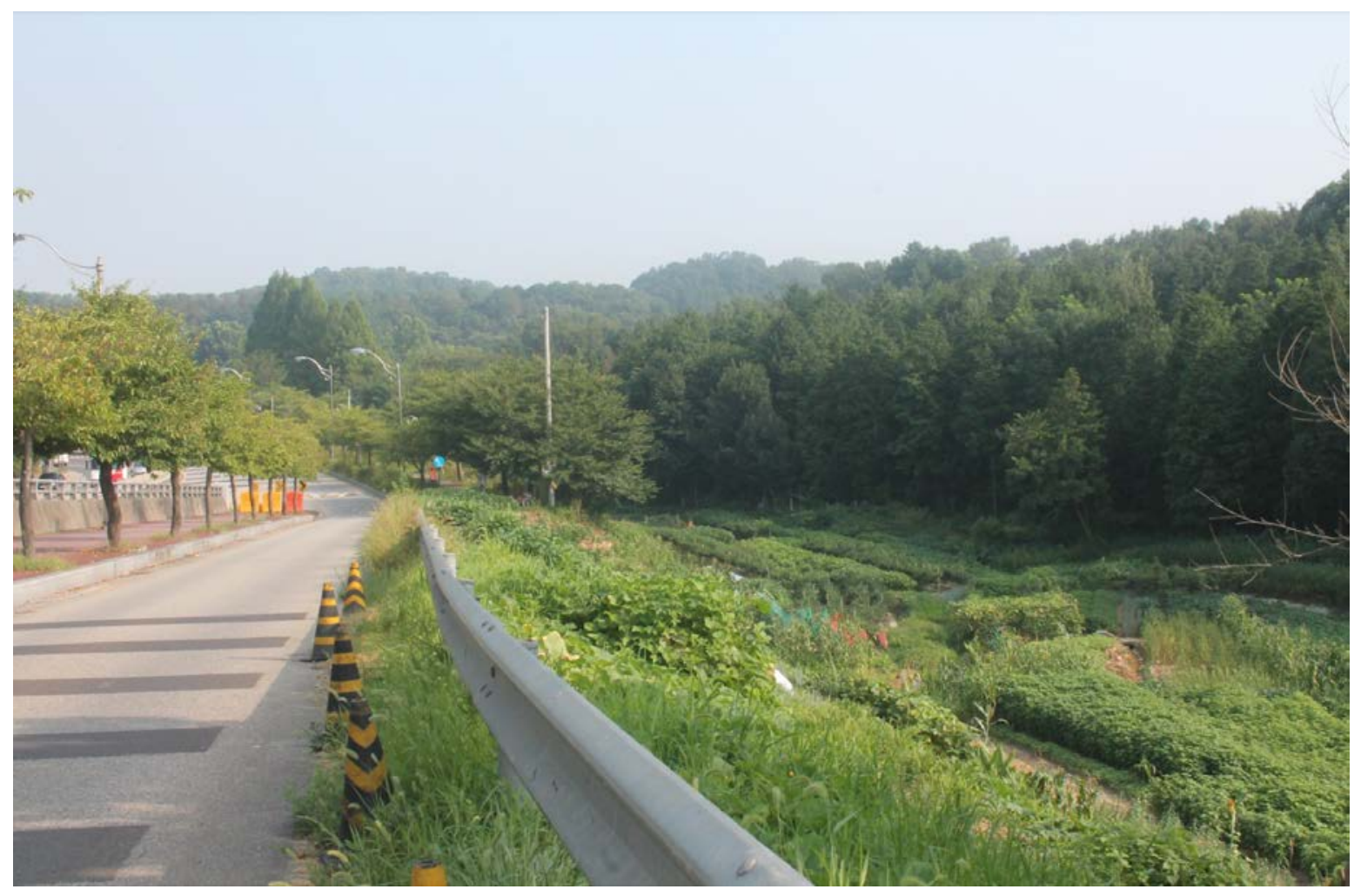

Figure 33 farmland around Chonbuk National University that is supposed to be parking lot

Most recurring terms related to the food quality that farmers cared about were mainly

pesticide-free food and healthy food. It seemed as many of the farmers who participated in farming to feed their own family members cared about how the food was grown which was one of their main motivations for farming.

My husband was suffering from cancer and I wanted to feed him organic, chemicalfree food so I started growing my own food. I read many books concerning the cancer treatment and how to live a healthy life. Even if we have money and there is food everywhere in supermarkets, there is not that much food to eat. They are all grown using pesticides and harmful chemicals. So I decided to grow my own 
healthy food for my family. -Song, an informal farmer around Chonbuk University, age 60

Growing my food cost more than when I try to buy from the market because I grow all types of vegetables and fruits and I'm the only farmer working. So it takes a lot of work to maintain everything by myself. But I still grow them because they are healthier than fruits and vegetables sold in the market. All of the vegetables that I grow are all organics. I know that most of the vegetables that we buy from the supermarket or markets are not as clean. They are grown with growth fertilizers and pesticides. -Kim, farmer in Mt. Gunji area, age 47

Four farmers out of six farmers have responded saying that the reason why they grow their own food is because 'they want to eat healthy'. This notion of healthy food overlaps with the 'quality' of food. Their concept of healthy food is not the kind of food that you get in corporate-owned supermarket, but rather the food that they produced on their own, an empowered food that they produced. Historically, the wanting of a healthier, locally grown food has always been a concept that lots of Koreans have desired. Uruguay Round in 1980 resulting in tariffs and international trade have brought up the concept of 신토불이(身土不

二), a belief that the domestic farm products are the best. In 1990s, the concept of 'well-

being' culture also appeared, as more Koreans became aware about health and wellness of their body ${ }^{76}$ All community residents practicing modest size farming to produce 'healthier' food that their family consumes also derives from the interest of the 'wellbeingness' of a body, a peak at how a health culture is formed in present Korea.

Through my qualitative research, local farming system in Jeonju's pattern was interpreted. Local food system in Jeonju focused on food production that resulted in a short food miles. It also showed that the mode of transportation was also very modest

\footnotetext{
76 Hong, Kyung-Wan, Ji-Young Kim, and Yang-Sook Kim. 2009. "The Conceptualization Of The Local Food, A Korean Case". 大韓經營學會誌 22(3): 1629-1649. Print.
} 
compared to that of mega scale farming, usually in short driving distance or walkable distance that takes less than 20 minutes of walking. This low ecological-impact of production produce pesticide-free food with almost no food waste, the kind of food that is embraced by the farmers who want to eat and live a healthy lifestyle. 
A local food system functioned as a social space where the participants of the food system are the co-producers of the city. Many of the local food system participants were able to actively participate in the community by engaging in food production and business, obtaining socio-cultural knowledge in the city of Jeonju. Cooperation of informal and formal institution pertaining local food system revealed its benefits of creating a platform that empowers and strengthens the community members. It also shows its resiliency in food system that minimizes the food waste and modes of food miles travelled to their local food system site. By understanding their possible interactions, a theoretical construct such as informal and formal institution can help to overcome the regulatory challenge that meet the actual need of the community, creating a socio-ecologically resilient city.

\section{Ch. 6 Conclusion}

\subsection{Limitation}

The limitation that had the greatest impact on my finding was based on the lack of quantitative data and the limited size of my samples. My ability to clearly answer the research questions and a hypothesis lacked due to the nature of qualitative analysis. As a result of heavy reliance on the qualitative data from informal data set, my research did not have a definite quantitative aspect in context and had to rely mostly on words of interviewees. Since most of the data context in my research was focused on informality, many of the interviewees could not provide me with any of the quantitative data as well. Most of the data that I drew from methods such as observation and interviews missed in specificity of the data and focused mainly on participant's personal experience, which could have been manipulated or transcribed wrongly. Also the specificity of the data 
could not be drawn for the reason of my limited sample size. Restricted sample size in a qualitative data does not necessarily reflect the data of entire population of Jeonju. For the future research, my limitation can be improved by engaging in a research that focuses more on quantitative data analysis. This can be done with more flexibility in time and resource, with an opportunity for more in-depth analysis that enhances the robustness of the data collected.

\subsection{Conclusion}

Researching about a local food system in Jeonju, South Korea has proved different aspects of local food system that represent cultural heritage associated with local food system. Local food system in Jeonju operated in a manner where both informality and formality of food system are easily spotted. Informal activities such as selling food in open-aired sidewalk market and growing food informally in a vacant land have followed its own set of rules assumed with socio-cultural heritage which was derived from cultural and historical background of Jeonju. What differentiates these informal activities in a global context is its embracement of informality from institutionalized regulations, providing flexible policies in land regulation and economic exchange process. The concept of flexibility, such as flexibility of food price in business also existed in between the participants of food system. These flexible activities derived from a more direct exchange of food business that built personal relationships and trust with other community resident members. Socio-cultural benefits in engagement of flexible local food system portrayed what kind of values were appreciated through representation of cultural and social dynamics in Jeonju. The clear representation of cultural dynamics has also reflected the aging population of agricultural sector and its small scale of farming in 
South Korea, resulting in a more self-reliant community that is ecologically resilient. This type of ecological impact proved that the engagement of local food system reduces food waste and shortens the food travelling distance between producers and consumers, as well as participants' empowerment to produce 'healthy' and 'natural' food. In hence, the local food system in Jeonju, South Korea confirmed its self-sufficiency through sociocultural benefits of building a community oriented city that is also ecologically resilient.

\subsection{Recommendation for Future Planners}

My research was an explanatory research to see whether a local food system in urban space create a more community friendly and ecologically resilient city. In a space where participants of food system are respected, participants can build a sense of community friendship by following and practicing cultural heritage. These activities also enable the community residents to be more aware of their food and surrounding areas as a social space. These aspects of food system in Jeonju consist of informal and formal institution's collaboration, shows a relationship of ecological resilience and socio-cultural benefits. This is important to consider in designing a city space, especially since urban space is often times neglected with incorporating food system. Urban designers have to take consideration of informality and the scale of food system that reflects cultural heritage. Such a case proves an importance of cooperation of local community and the formal institution that recognizes its cultural and social dynamics in a space. Food is an efficient medium tool that produces social capital for human centric community. Therefore, city planners should acknowledge a local food system as in their designing 
process that creates an urban space where the city residents can share memories, experiences, stories, and values based on trust. 


\section{Appendix}

\section{Appendix 1 Land Registration Map}

지적도 등본

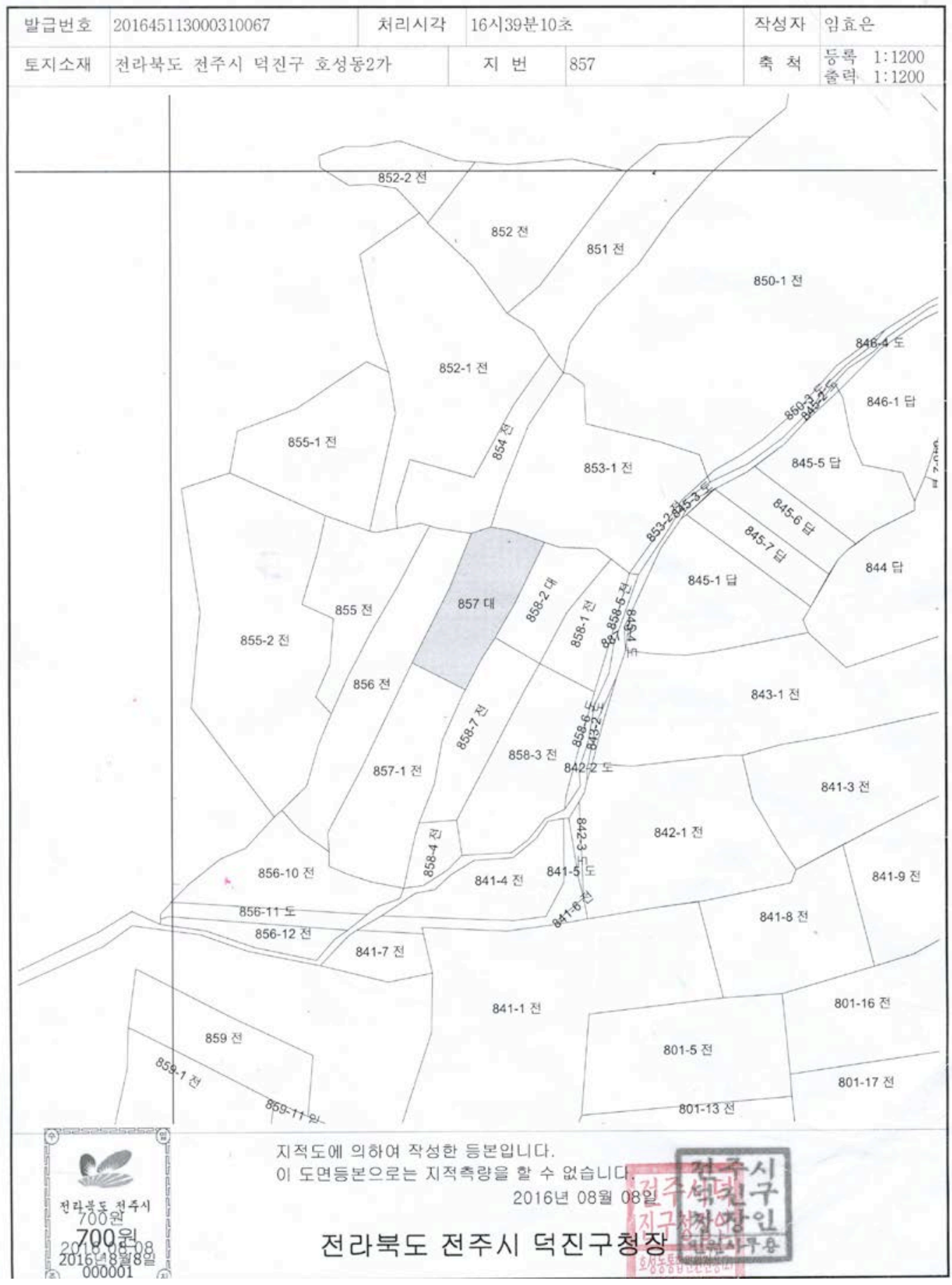


Appendix 2 Status of Street Vendor Provisional Allowance Area

\section{남부시장 가설점포}

설치기간 : $2001.4 .16 \sim 5.8$.

○ 사 업 비 : 315백만원 (99년 명시 115 / 2001년 본예산 200)

점 포 수 : 188 칸 (3칸 - 사무실), 도로연장 $400 \mathrm{~m}$

○ 계약대상 : 성실사용자에 한해 매년 7 월 1 년 단위 재계약

$\bigcirc$ 관리내용 : 1년 2회 이상 실태점검 및 위반자 계약해지

계약현황

\begin{tabular}{|c|c|c|c|c|c|c|}
\hline 구 분 & 총 계 & 계약점포 & 빈점포 & 사용불가 & 공용 & 비고 \\
\hline 점포수 & 188 개소 & 94 개소 & 94개소 & $\begin{array}{c}11 \text { 개소 } \\
\text { (나무,전봇대) }\end{array}$ & $\begin{array}{c}\text { 3개소 } \\
\text { (사무실,초소) }\end{array}$ & \\
\hline
\end{tabular}

Current Status of Nambu Vendor Cubbies

노점상 잠정허용구역 현황

\begin{tabular}{|c|c|c|c|c|c|c|c|}
\hline 위 치 & 노점상수 & 허용시간 & 생성연도 & 연장(m) & 면적 $\left(\mathrm{m}^{2}\right)$ & 사 & 비 고 \\
\hline 매 곡 교 & 150 & $\begin{array}{l}\text { 새벽)04:00 10:00 } \\
\text { 평일)16:00 22:00 } \\
\text { 휴일)10:00 22:00 }\end{array}$ & 1988 & 260 & 160 & - 영세상인 생계보호 & \\
\hline 서부시장 & 55 & $\begin{array}{l}\text { 평일)16:00 22:00 } \\
\text { 휴일)10:00 - } 22: 00\end{array}$ & 1992 & 120 & 240 & 영세상인 생계보호 & \\
\hline $\begin{array}{l}\text { 평화주공 } \\
1 \cdot 2 \text { 단지 }\end{array}$ & 33 & $\begin{array}{l}\text { 평일)16:00 22:00 } \\
\text { 휴일)10:00 22:00 }\end{array}$ & 1993 & 150 & 252 & $\begin{array}{l}\text { - 인근에 시장이 없어 직장인 및 주민 } \\
\text { 장보기 편의제공 }\end{array}$ & \\
\hline 삼익수영장 & 155 & $\begin{array}{l}\text { 평일)16:00 22:00 } \\
\text { 휴일)10:00 22:00 }\end{array}$ & 1992 & 700 & 750 & $\begin{array}{l}\text { - 인근에 시장이 없어 직장인 및 주민 } \\
\text { 장보기 편의제공 }\end{array}$ & \\
\hline $\begin{array}{l}\text { 서신2지구 } \\
\text { (세터마을, } \\
\text { 비사벌APT) }\end{array}$ & 152 & $\begin{array}{l}\text { 평일)16:00 22:00 } \\
\text { 휴일)10:00 22:00 }\end{array}$ & 1997 & 610 & 1,525 & $\begin{array}{l}\text { · 인근에 시장이 없어 직장인 및 주민 } \\
\text { 장보기 편의제공 }\end{array}$ & \\
\hline 중앙성당 & 58 & $\begin{array}{l}\text { 평일)16:00 } 22: 00 \\
\text { 휴일)10:00 22:00 }\end{array}$ & 1980 & 190 & 450 & $\begin{array}{l}\text { · 도심지에 위치하고 있어 직장인 퇴근길 } \\
\text { 장보기 편의제공 }\end{array}$ & \\
\hline $\begin{array}{l}\text { 남부시장 } \\
9\end{array}$ & 90 & 상설운영 & $\begin{array}{l}1988 \\
(2001)\end{array}$ & 400 & 680 & - 영세상인 생계보호 & 가설점포 \\
\hline 객사뒤편 & 17 & 상설운영 & 1988 & 150 & 300 & $\begin{array}{l}\text { - } 80 \text { 년경 객사주변에 산발적으로 } \\
\text { 노점상행위를 하던 사람들을 } 88 \text { 올림픽때 } \\
\text { 객사뒷편에 유도정착 }\end{array}$ & 가설점포 \\
\hline
\end{tabular}




\section{Appendix 3 Land Use Planning Manual}

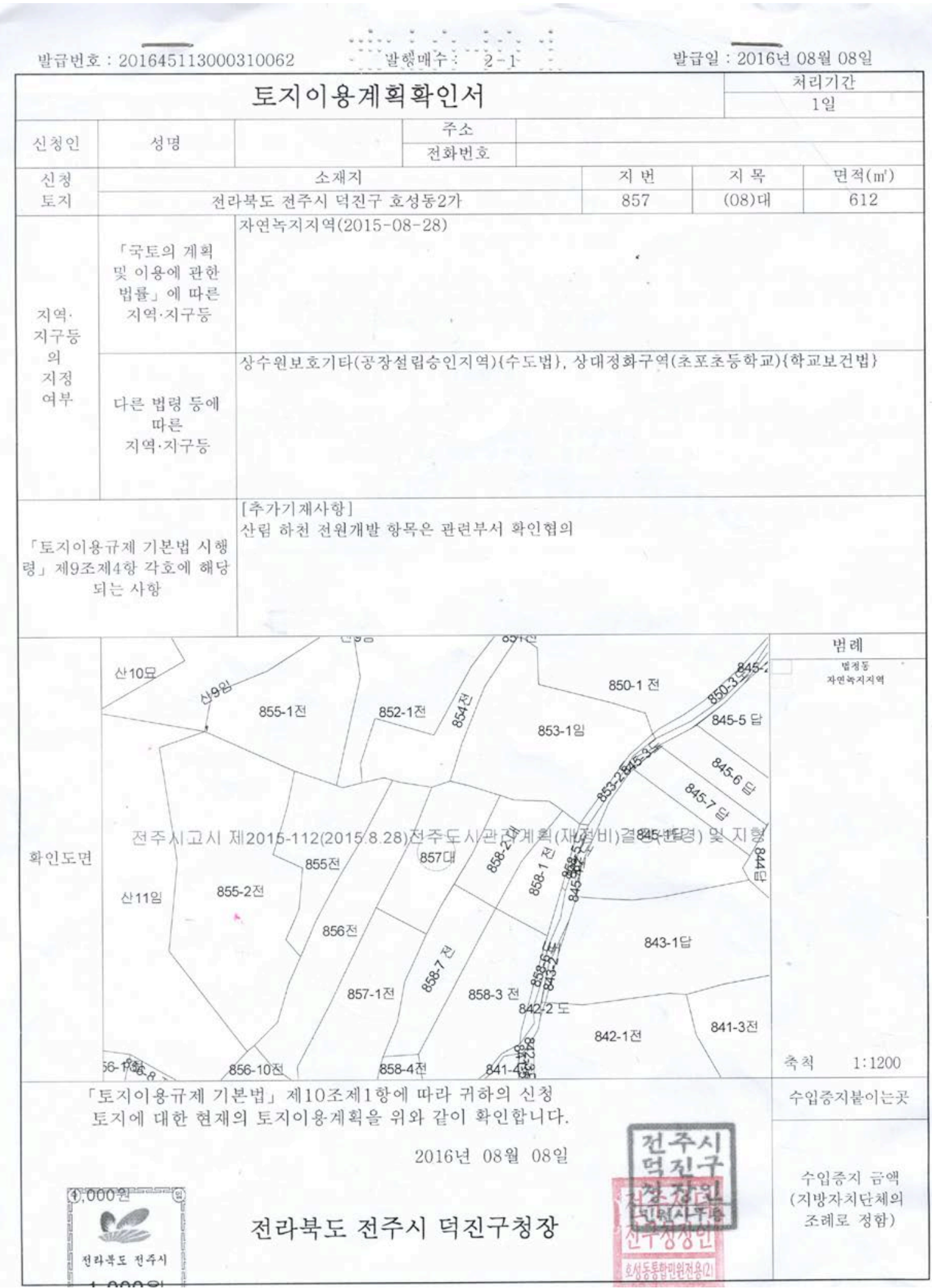


Appendix 4 Architectural Criteria of the Construction for the Land Use District

용도지역별 건축기준 조견표(시행령 제71조 별표2 별표22/2014년 11월 4일 기즌)

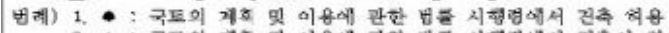

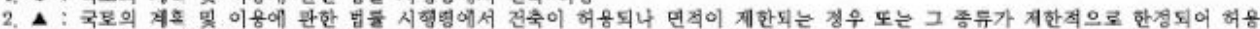

3, 으: 도시·군계쵝조례로겨 건축 해용

4. $\triangle$ : 도시·군게첵조례로셔 건축이 혀용되나 며젹이 게한되는 갱우 또는 그 증류가 제한격으로 한경되어 여용

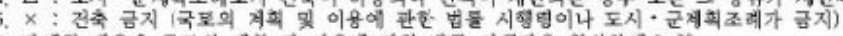

6. 자세한 내용은 추호의 계혁 몿 이용에 퐌한 법률 시형령을 확언하셔요.

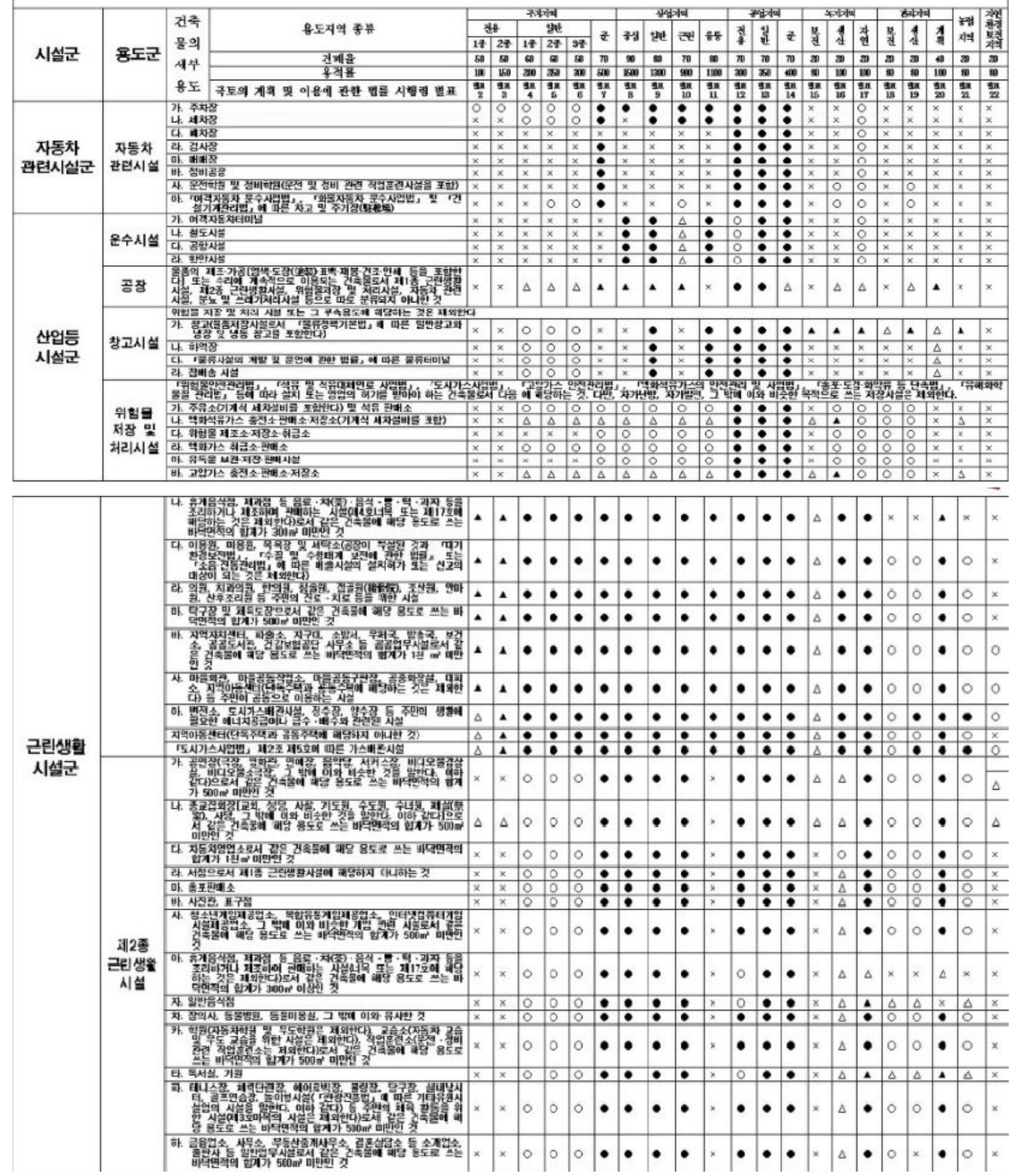


Appendix 5 Zoning Ordinance map of Jeonju

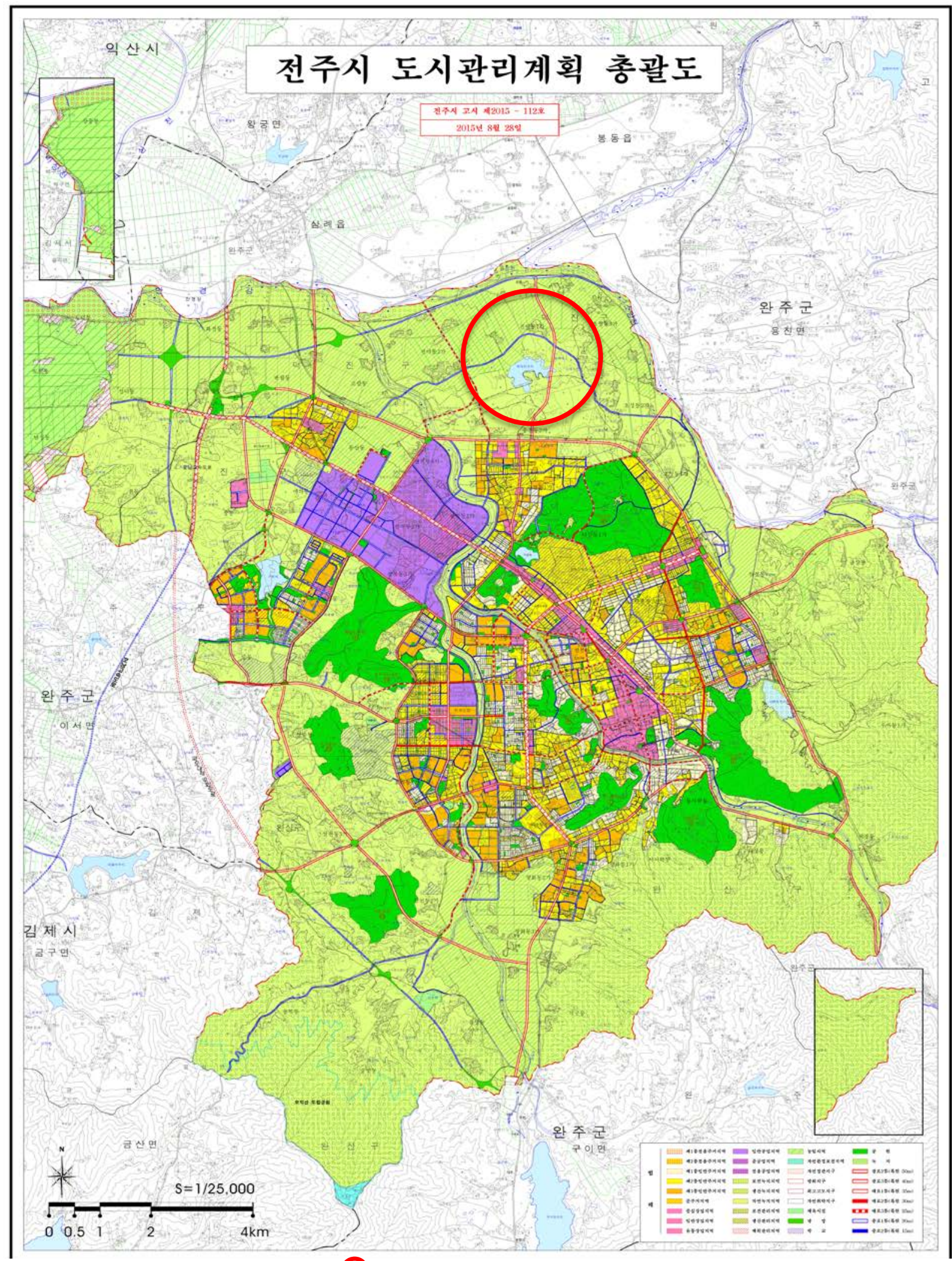

Green zones are Nature Preserved Land $\mathrm{O}=$ Mt. Gunji in Hosung dong, Deokjin Gu 


\section{Works Cited}

Adger, W.N. 2000. “'Social and Ecological Resilience: Are They Related?’ Progress in Human Geography 24:347-64.

American Community Gardening Association. Undated. Frequently Asked Questions. Available at Web site http://www.communitygarden.org/learn/faq.php

"A Whole Community Approach To Emergency Management: Principles, Themes, And Pathways For Action". FEMA FDOC 104-008-1 (2011): 1-23.

Barr, Stewart, and Patrick Devine-Wright. 2012. "Resilient Communities: Sustainabilities In Transition". Local Environment 17(5): 525-532.

Berkes, F. and C. Folke. 1998. “'Linking Social and Ecological Systems for Resilience and Sustainability.” Pp. 1-25 in Linking Social and Ecological Systems: Management Practices and Social Mechanisms for Building Resilience, edited by F. Berkes and C. Folke. Cambridge: Cambridge University Press.

Besthorn, F.H. 2013. Vertical farming: Social work and sustainable urban agriculture in an age of global food crises. Australian Social Work 66(2): 187-203.

Buchan, Robert, Denise Cloutier, Avi Friedman, and Aleck Ostry. 2015. "Local Food System Planning: The Problem, Conceptual Issues, And Policy Tools For Local Government Planners". Canadian Journal Of Urban Research Summer 24 (1): 1-23.

Carolyn Dimitri, Lydia Oberholtzer, Andy Pressman. 2016. "Urban agriculture: connecting producers with consumers", British Food Journal,118(3) : 603-617.

Carpenter, S. and L. Gunderson. 2001. "Coping with Collapse: Ecological and Social Dynamics in Ecosystem Management.” Bioscience 51:451-57.

Cho, Eunjin, and Jong Oh Lee. "Local Food Station Of Wanju-Gun As A Platform". Advanced Science and Technology Letters 52 (2014): 153-159. Print.

Choi, Young-Chool, and Hak-Sil Kim.2015. "Success Factors Of The Local Food Movement And Their Implications: The Case Of Wanju-Gun, Republic Of Korea". Procedia Economics and Finance 23 :1168-1189. Web.

Chul, JungMan, and David Pearson. 2014. "The Current Status and Potential of Local Food in South Korea." The Australasian-Pacific Journal of Regional Food Studies 4:6178.

Cohen, N. and Reynolds, K. 2014. “Urban agriculture policy making in New York’s 'new political spaces' strategizing for a participatory and representative system”, Journal of Planning Education and Research, 34(2): 221-234. 
Cohen, N., Reynolds, K. and Sanghvi, R. 2012. "Five Borough Farm: Seeding the Future of Urban Agriculture in New York City”. Design Trust for Public Space, New York, NY.

Cook, Karen S., Nan Lin, and Ronald Stuart Burt. 2001. Social Capital: A Theory Of

Social Structure And Action. 1st ed. New York: Cambridge University Press.

De Groot, Rudolf S, Matthew A Wilson, and Roelof M.J Boumans. 2002. "A Typology For The Classification, Description And Valuation Of Ecosystem Functions, Goods And Services". Ecological Economics 41.3: 393-408.

Denzin, Norman K., and Yvonna S. Lincoln. The Sage handbook of qualitative research. Los Angeles: Sage, 2018 : 732

Dovey K (2012) Informal urbanism and complex adaptive assemblage. International Development Planning Review. 34 (4): 349-67.

Elder, G., Pavalko, E. K., \& Clipp, E. C.(1993).Working with archival lives: Studying lives (Sage University Papers on Quantitative Applications in the Social Sciences, 07088).Newbury Park, CA: Sage

"FAO - COMMITTEE ON WORLD FOOD SECURITY". Fao.org. N.p., 2017. Web. 28 Apr. 2017.

Field, D.R. and W.R.J. Burch. 1988. Rural Sociology and the Environment. Connecticut: Greenwood Press.

Hansen TB, Verkaaik O. 2009. Urban charisma: on everyday mythologies in the city. Critique of Anthropology 29 (5): 5-26.

Hart, K. 1973. 'Informal Income Opportunities and Urban Employment in Ghana'. Journal of Modern African Studies, 11: 61-89.

Hillenkamp, Isabelle, Frédéric Lapeyre, and Andreia Lemaître. Securing Livelihoods. 1st ed. Oxford University Press, 2004.

Hirsch, Darya, Meyer, Christian, H., Klement, Johannes, Hamer, Martin and Terlau, Wiltrud. 2016. 8. 01. "Urban Agriculture and Food Systems Dynamics in the German Bonn/Rhein-Sieg Region.” International journal on food system dynamics 7(4): 341-359.

Hong, Kyung-Wan, Ji-Young Kim, and Yang-Sook Kim. 2009. "The Conceptualization Of The Local Food, A Korean Case". 大韓經營學會誌 22(3): 1629-1649. Print.

Hopkins, R., 2008. The transition handbook. Totnes: Green Books. 
Howe, J. 2002. Planning for urban food: The experience of two UK cities. Planning Practice and Research 17(2): 125-144.

Inman, Patricia. 2017. "Locally Produced Food: A Way To Grow". Policy Profiles 15 (2): $1-7$.

Inman, Patricia. 2017. "Regional Food Systems As Engines : How Do Universities Engage?". Social Alternatives 34(2) : 39-46.

Jeonju City Council. "Current Status.". N.p., n.d. Web. 27 Apr. 2017. <http://jeonju.go.kr/index.9is?contentUid=9be517a74f8dee91014f920f4d7e10bb>.

Jeonju Hanok Village [Slow City] (전주한옥마을 [슬로시티])| Official Korea Tourism Organization". English.visitkorea.or.kr. N.p., 2017. Web. 27 Apr. 2017.

Kortright, R., and S. Wakefield. 2011. Edible backyards: A qualitative study of household food growing and its contributions to food security. Agriculture and Human Values 28: 39-53.

Koster Martijin.2014. Fear and intimacy: citizenship in a Recife Slum, Brazil. Ethnos 79 (2): 215-37.

Koster, Martijn, and Monique Nuijten. 2016. "Coproducing Urban Space: Rethinking The Formal/Informal Dichotomy". Singapore Journal of Tropical Geography 37(3): 282294. Web.

Krikser, Thomas, Annette Piorr, Regine Berges, and Ina Opitz. 2016. "Urban Agriculture Oriented Towards Self-Supply, Social And Commercial Purpose: A Typology". Land 5 (3): 1-19.

Kupers, Roland. 2014. Turbulence: A Corporate Perspective On Collaborating For Resilience. 1st ed. Amsterdam University Press. Print.

Lobley, M., J.R. Baker and I. Whitehead (2010) Farm succession and retirement: some international comparisons. Journal of Agriculture, Food Systems, and Community Development 1(1): 49-64

Locke, C., W.N. Adger, and M. Kelly. 2000. “'Changing Places Environmental Impact of Migration.’' Environment 42:24-39.

Marshall, N. A. et al. "How Resource Dependency Can Influence Social Resilience Within A Primary Resource Industry". Rural Sociology 72(3) (2007): 359-390.

McCarthy, R. and Moon, J. 2012. "The economic impact of farmers markets: A study of nine markets in three major cities"

http://www.marketumbrella.org/index.php?mact=News,cntnt01,detail,0\&cntnt01articleid $=163 \&$ cntnt01returnid=83. 
McKibben, Bill. 2010. Eaarth. 1st ed. New York: Times Books.

Meerow, Sara, Joshua P. Newell, and Melissa Stults. 2016. "Defining Urban Resilience: A Review". Landscape And Urban Planning 147: 38-49.

doi:10.1016/j.landurbplan.2015.11.011. 39.

Mehmood, Abid. 2015. "Of Resilient Places: Planning For Urban Resilience". European Planning Studies 24 (2): 407-419.

Morgan, Kevin. 2009. "Feeding The City: The Challenge Of Urban Food Planning". International Planning Studies 14 (4): 341-348.

Mougeot, L.J. 2000. "Urban agriculture: definition, presence, potentials and risks”, in Bakker, N.,Dubbeling, M., Guendel, S., Sabel-Koschella, U. and de Zeeuw, H. (Eds), Growing Cities, Growing Food: Urban Agriculture on the Policy Agenda, DSE, Eurasburg : 1-42.

Norberg-Hodge, Helena. "Reclaiming Our Food : Reclaiming". The Ecologist 29(3) (1999): 209-215. Print.

Oluoko-Odingo, Alice Atieno. 2011. "Vulnerability And Adaptation To Food Insecurity And Poverty In Kenya". Annals of the Association of American Geographers 101(1): 120.

Opitz, Ina, Regine Berges, Annette Piorr, and Thomas Krikser. 2015. "Contributing To Food Security In Urban Areas: Differences Between Urban Agriculture And Peri-Urban Agriculture In The Global North". Agriculture And Human Values 33 (2): 341-358.

Petcou, Constantin, and Petrescu, Doina. 2015. "R-URBAN or how to co-produce a resilient city." Ephemera: Theory \& Politics In Organization 15(1): 249-262.

Pothukuchi, Kameshwari. 2015. "Five Decades Of Community Food Planning In Detroit". Journal Of Planning Education And Research 35 (4): 419-434.

Pothukuchi, K. \& Kaufman, J.L. 1999. "Placing the food system on the urban agenda: The role of municipal institutions in food systems planning”. Agriculture and Human Values 16: 213-224.

"Private Letter Ruling 200818028 ". irs.gov. N.p., 2008. Web. 29 Apr. 2017.

Rezai, Golnaz, Mad Nasir Shamsudin, and Zainalabidin Mohamed. 2016. "Urban Agriculture: A Way Forward To Food And Nutrition Security In Malaysia". Procedia Social And Behavioral Sciences 216: 39-45.

Rodgers, L. 2001. “'Ownership and Motivation.” The Ownership Culture Report 1(4):14. Cambridge, MA: Ownership Associates. 
Riley, Mark. 2014. "Still Being The 'Good Farmer': (Non-)Retirement And The Preservation Of Farming Identities In Older Age". Sociologia Ruralis 56(1): 96-115.

Rogus, Stephanie, and Carolyn Dimitri. 2014. "Agriculture In Urban And Peri-Urban Areas In The United States: Highlights From The Census Of Agriculture". Renewable Agriculture And Food Systems 30 (01): 64-78.

Shuman, M. 1998. Going Local: Creating Self-Reliant Communities in a Global Age. New York:The Free Press.

Stedman, R.C. 1999. "Sense of Place as an Indicator of Community Sustainability."' The Forestry Chronicle 75:765-70

Steel, Carolyn. 2013. Hungry City. 1st ed. London: Vintage.

"The Informal Food Sector Municipal Food Support Policies For Operators". Food and Agriculture Organization of the United Nations 4 (2003): 1-23.

Trivette, Shawn A. "How Local Is Local? Determining The Boundaries Of Local Food In Practice". Agriculture and Human Values 32.3 (2014): 475-490. Web.

Vale, Lawrence J. 2013. "The Politics Of Resilient Cities: Whose Resilience And Whose City?". Building Research \& Information 42(2): 191-201.

Van Veenhuizen, R. 2006. Cities Farming for the Future-Urban Agriculture for Green and Productive Cities; RUAF Foundation, IDRC and IIRR Publishing: Silang, Philippines.

Van Passel, Steven. 2010. "Food Miles To Assess Sustainability: A Revision". Sustainable Development 21(1): 1-17.

Wilkinson, C. 2011. "Social-Ecological Resilience: Insights And Issues For Planning Theory". Planning Theory 11(2): 148-169.

Zelizer, Viviana A. The Purchase Of Intimacy.. 1st ed. Princeton: Princeton University Press, 2008. Print. 